University of San Diego

Digital USD

1983

\title{
Attitudes of Teachers and Administrators toward the Handicapped in Malaysia and Implications for Teacher Training and Program Development
}

Rachel Mathews EdD

University of San Diego

Follow this and additional works at: https://digital.sandiego.edu/dissertations

Part of the Leadership Studies Commons

\section{Digital USD Citation}

Mathews, Rachel EdD, "Attitudes of Teachers and Administrators toward the Handicapped in Malaysia and Implications for Teacher Training and Program Development" (1983). Dissertations. 481.

https://digital.sandiego.edu/dissertations/481

This Dissertation: Open Access is brought to you for free and open access by the Theses and Dissertations at Digital USD. It has been accepted for inclusion in Dissertations by an authorized administrator of Digital USD. For more information, please contact digital@sandiego.edu. 


\title{
ATTITUDES OF TEACHERS AND ADMINISTRATORS TOWARD THE HANDICAPPED IN MALAYSIA AND IMPLICATIONS FOR TEACHER TRAINING AND PROGRAM DEVELOPMENT
}

\author{
by \\ Rachel Mathews \\ A dissertation submitted in partial fulfillment \\ of the requirements for the degree of \\ Doctor of Education \\ University of San Diego \\ 1983 \\ Dissertation Committee \\ Rosalie G. Rhoads, Ph.D., Director \\ DeForest L. Strunk, Ed.D. \\ Susan M. Zgliczynski, Ph.D. \\ Prof. John S. Chambers, Jr.
}


ATTITUDES OF TEACHERS AND ADMINISTRATORS TOWARD THE

HANDICAPPED IN MALAYSIA AND IMPLICATIONS FOR

TEACHER TRAINING AND PROGRAM DEVELOPMENT

MATHEWS, RACHEL, Ed.D. University of San Diego, 1983.

Director: Rosalie Rhoads, Ph.D. $132 \mathrm{pp}$.

The primary purposes of this study were to investigate the attitudes of teachers ana principals based on demographic and experiential variables and to make recommendations for teacher training and program development based on the results of the study. Subjects were $(N=450)$ elementary schoolteachers and $(\mathrm{N}=30)$ principals from the state of Selangor in Malaysia. The Attitude Toward Handicapped Individuals Scale (ATHI) and a personal data questionnaire including two open-ended questions related to the treatment of the handicapped and categorical preferences for exceptionalities were used in this survey research. Ninety-two percent of the questionnaires were returned with $87 \%$ being scorable.

The independent sample $\underline{t}$ test and one-way analysis of variance were used to investigate the effect of sex, age, race, academic qualification, teaching experience, contact with handicapped persons, and attendance in presentations 
related to special education, and attitudinal differences between teachers and principals. Chi-square was used to investigate hypotheses regarding differences in responses to individual items on the ATHI scale. The preferences for various categories of exceptionalities and choice of specific settings for delivery of instruction were also investigated.

Results indicated that educators with Bachelor degrees possessed the highest level of acceptance of handicapped persons. Respondents from the Indian ethnic group were found to exhibit more favorable attitudes than respondents from Chinese and Malay ethnic groups. Subjects who had attended presentations related to special education indicated higher acceptance of handicapped persons than subjects without such experiences. Overall the subjects were found to possess stereotypic negative attitudes toward the disabled. A hierarchy of categorical preference was found to exist among educators. The study also indicated that educators favored segregated schools and communities for handicapped individuals. Item analysis of the ATHI indicated that the educational background and race of the subjects had significant infiuence on the subjects' perceptions of handicapped persons' socialization capability, mental and emotional potential, and self-concept.

Implications of this study suggested preservice, inservice, and program development for handicapped individuals 
in Malaysia. Based on the study, guidelines were suggested for preservice, inservice, and program development.

Recommendations for further attitudinal studies were made based on the results and limitations of the present study. 
DEDICATION

This Dissertation is Dedicated to:

My husband, Varughese

\begin{abstract}
Whose unfailing love, optimism, and support carınot be expressed in words. Without his inspiration and encouragement the entire process of study would have never begun and this dissertation would have never been completed.

My daughter, Rayvey
Whose understanding, patience, and love made my dreams a reality.

My parents Mr. and Mrs. Thomas

Whose training contributed to my educational advancement, perseverance, and inspiration.
\end{abstract}


ACKNOWLEDGMENTS

I am indebted to many people in several ways for the successful completion of this research. I wish to express my greatest appreciation and thanks to Dr. Rosalie Rhoads, the Director of my dissertation committee, for her guidance, understanding, time, reassurance, thoughtful criticism, patience, and interest auring the completion of this study. She provided me with the opportunity to learn and grow and has helped me define a path for continued growth. My deepest acknowledgement is extended to my major program advisor and committee member, Dr. DeForest Strunk, for the many hours spent in consultation. His constructive criticism, encouragement, interest, and support were exceptionally valuable and beneficial to this study. He assisted me in seeking another challenge in my educational career and attaining what seemed to be an insurmountable goal.

A special note of appreciation and thanks is given to Dr. Susan Zgliczynski, also a member of my committee. Through her expertise invaluable assistance was provided in the design of the study and particularly in the statistical process and data analyses. Her continuous enthusiasm, constructive criticism, and encouragement were 
invaluable to this study. I owe her for whatever methodological and statistical sophistication I acquired during this time.

My greatest appreciation is expressed to Prof. John Chambers, my committee member for his interest, and contributions to this manuscript. I would like to gratefully acknowledge the understanding, concern, interest, and support shown by Dr. Edward DeRoche, Dean of the School of Education, each and every member of the faculty, and all staff at the School of Education, especially Mrs. Pat Martin, Secretary. I will treasure the memories of my studies at the University of San Diego, and specifically the warm and generous people in the school of Education.

I wish to express my heartfelt thanks to my friends and fellow students for their love and support throughout this difficult, but meaningful learning experience. A special appreciation is expressed to Ms. Florence Johnson, Ms. Judith Edwin, and Ms. Stephannie Tarkington who shared my joys, frustrations, and sorrows with me. My special note of thanks to Florence for typing and providing helpful suggestions in preparation of this manuscript. I also wish to specially thank Ms. Joanna Bedalov for providing editorial assistance with the final draft of this manuscript.

I am grateful to the Ministry of Education of Malaysia for giving me the permission to collect data from educators 
in Malaysia. I also want to thank the respondents of this study for their valuable information and cooperation.

My greatest gratitude belongs to my family for their constant love and support. A special appreciation is reserved for my husband Lt. Col. V. Mathews whose love, inspiration, sacrifices, and assistance are beyond my words. He diligently helped me in the data collection of this project. His encouragement has allowed me to grow as a person and as an edurator. My daughter, Rayvey Mathews, shared with me the valuable experiences of my daily living, learning, and growing. She encouraged and supported me and remained confident in anticipation of the project's completion. My sincere appreciation to my parents, sisters, brothers, and all my in-laws. Although separated by thousands of miles, they all provided me with loving support, encouragement, anà continual prayers.

Above all, I wish to express the credit of all my achievements to the Lord Almighty. Without His tender mercies and presence, my life would not have been worthwhile. 
DEDICATION . . . . . . . . . . . . . . . $i i$

ACKNOWLEDGEMENTS . . . . . . . . . . . . . . i ii

LIST OF TABLES . . . . . . . . . . . . . . . $\mathrm{x}$

LIST OF APPENDICES . . . . . . . . . . . . . . . xii

Chapter

I. INTRODUCTION . . . . . . . . . . . . . . . 1

Statement of the Problem . . . . . . . . 4

Statement of Hypotheses and Rationale . . . 5

Definition of Terms . . . . . . . . 7

Significance of the study . . . . . . . 9

Assumptions of the study . . . . . . . . 9

Limitations of the study . . . . . . . 10

II. REVIEW OF THE LITERATURE . . . . . . . . . 11

Attitudinal Scales . . . . . . . . . 11

Attitude Toward Disabled Persons
Scale (ATDP)...................... 12

Reliability of ATDP . . . . . . . . 13

Validity of ATDP . . . . . . . . . 13

Attitude Toward Handicapped

Individuals Scale (ATHI) . . . . . . . 14

Attitude Toward the Handicapped

in the United States.......... 15

$v i$ 
Methods for Attitude Modification . . . .

Attitude Toward the Handicapped

in Malaysia . . . . . . . . . . .

Special Education in other

Developing Asian Countries......

Summary of the Review of the

Literature............. . 37

III. RESEARCH DESIGN AND METHODOLOGY . . . . . . 40

Selection of Schools and Sample . . . . . 40

Description of Instrumentation . . . . . 41

Attitude Toward Handicapped

Individuals Scale (ATHI) . . . . . .

Aaministration of Attitude Toward Handicapped Individuals Scale . . . 43

Test battery . . . . . . . . . . 44

Validation of the Translation of the ATHI Scale into Bahasa Malaysia . . . . 45

Procedures for Collection of Dissertation Data . . . . . . . . 47

Methods of Data Analysis . . . . . . 47

IV. ANALYSIS OF DATA . . . . . . . . . . . 49

Presentation of the Data . . . . . . . . 49

Total Scores of the Respondents
on the ATHI Scale ........... 50

Testing the Hypotheses . . . . . . . 51

Hypothesis 1. . . . . . . . . . 52

Hypothesis 2. . . . . . . . . . 54

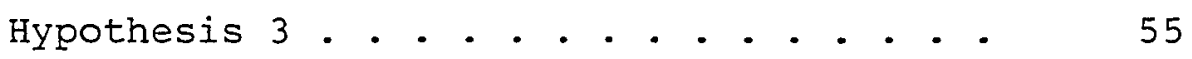

Hypothesis 4........... . . 57

Hypothesis 5........... . . 59

vii 


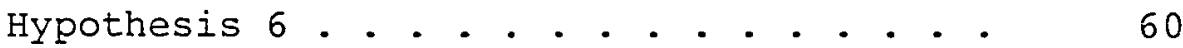

Hypothesis 7 . . . . . . . . . 61

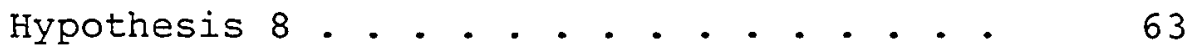

Respondents' Choice of Delivery of

Instruction for the Handicapped . . . .

Respondents' Priority of Working with

Different Categories of Exceptionality . .

Analysis of Respondents' Scores on

Individual Items of ATHI Scale... . . 67

Discussion of Results . . . . . . . . 72

V. SUMMARY, CONCLUSIONS, IMPLICATIONS,

AND RECOMMENDATIONS . . . . . . . . . . 78

Summary • . . . . . . . . . . . . 78

Research Design and Instrument . . . . 79

Sample . . . . . . . . . . . 79

Procedure .............. 80

Analysis of Data . . . . . . . 80

Findings .............. 80

Conclusions .............. . . 84

Implications . . . . . . . . . . . 85

Inservice Training . . . . . . . . . . 86

Objectives . . . . . . . . . . 89

Lecture Strategy . . . . . . . . . 89

Handicapped Awareness Simulation . . . . 90

Preservice Training . . . . . . . . . 90

Suggested Preservice Teacher
Training Program......... . . . . 91

Degree program . . . . . . . . . 91

viii

Reproduced with permission of the copyright owner. Further reproduction prohibited without permission. 


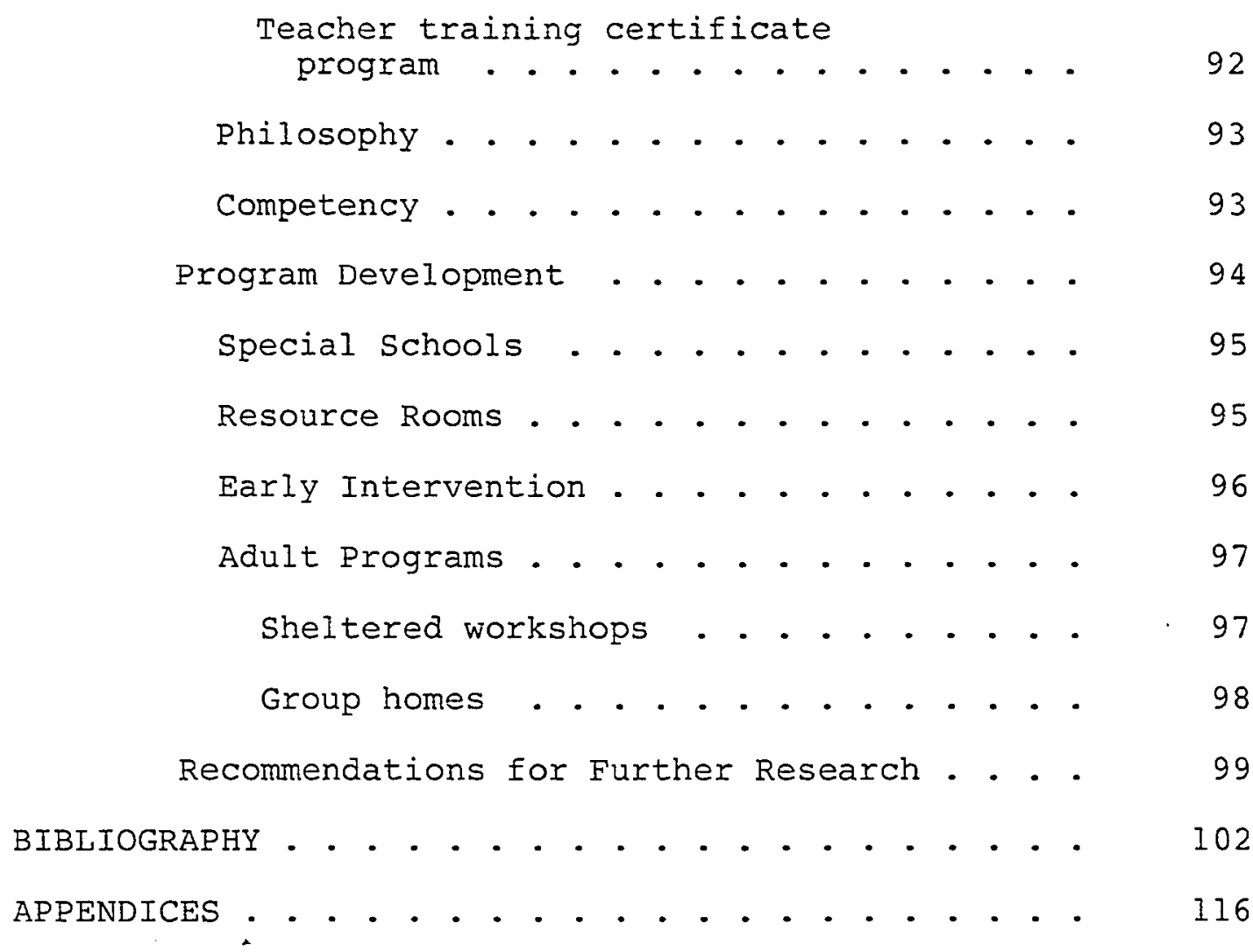


1. Number and Percentage of Survey Respondents from Elementary schools in Selangor, Malaysia . . . . . . . . . . . .

2. Scores on ATHI Scale by Teachers and Principals... . . . . . . . . .

3. Percentage of Teachers and Principals Scoring More than 70 points on the ATHI Scale................

4. Scores on ATHI by Respondents Attenāed Presentations Related to Special Education . . . . . . . . . . . . . .

5. Comparison of Respondents' Scores on ATHI According to Attendance in Presentations Related to Special Education . . . . . .

6. Scores on ATHI According to the Type of Relationship with Handicapped Individuals . . . . . . . . . . . . .

7. Comparison of Respondents' Scores on ATHI According to Type of contact by Analysis of Variance . . . . . . . . .

8. Scores on ATHI by Respondents According to Years of Teaching Experience . . . . .

9. Comparison of Respondents' Scores on ATHI According to Teaching Experience by Analysis of Variance . . . . . . . . .

10. Scores on ATHI by Respondents According to the Level of Education . . . . . . . .

11. Comparison of Respondents' Scores on ATHI by Analysis of Variance . . . . . .

12. Scores on ATHI by Teachers and Principals . . . . . . . . . . . . .

13. Comparison of Teachers' and Principals' Scores on ATHI by $t$ Test..........

14. Scores on ATHI by Males and Females . . . . 
15. Comparison of Male and Female Respondents' Scores on ATHI by $t$ Test..........

16. Scores on RTHI by Respondents Accoraing to Various Age Groups . . . . . . . . .

17. Comparison of the Respondents' Scores on ATHI by Analysis of Variance . . . . .

18. Scores on ATHI by Respondents According to Various Race Groups . . . . . . . . .

19. Comparison of the Respondents' Scores on ATHI by Analysis of Variance . . . . . . .

20. Number and Percentage of Respondents' Choice of Delivery of Instruction to the Handicapped . . . . . . . . . . .

21. Number and Percentage of Respondents' Preference for Working with Varicus Categories of Exceptionality . . . . . .

22. Hypotheses of Independence Rejected . . . . 
LIST OF APRENDICES

Appendix

Page

A. ATHI SCALE . . . . . . . . . . . . .

117

B. PERSENDIRIAN BORANG DATA

(Personal Data Form) . . . . . . . . . 121

C. COVER LETTER FOR SURVEY . . . . . . . . . 127

D. PERMISSION LETTER FROM THE MINISTRY

OF EDUCATION, MALAYSIA. . . . . . . . 129

E. SCORING THE ATHI.............. 131 


\section{CHAPTER I}

\section{INTRODUCTION}

Attitudes of teachers have a significant influence on academic performance and self-concept of their students (Rosenthal \& Jacobson, 1968). An attitudinal study is of paramount value in a developing nation like Malaysia because of the scarcity of such research in Maiaysia.

Malaysia, a country situated in Southeast isia; has a total population of 13 million people. The population consists of various ethnic groups with Malays, Chinese, and Indians constituting the major groups. The school age population is approximately $2,507,660--a b o u t ~ 20 \%$ of the population. Although education is not compulsory in Malaysia, 98\% of the normal children attend school. But only $2 \%$ of the handicapped children have the opportunity to attend school because of the shortage of special education facilities (see, 1983).

At present, there is an increasing and awakening concern by the parents of handicapped children in Malaysia for the welfare and training of handicapped individuals. As a result, several segregated schools operated by voluntary associations have developed to assist in meeting the needs of various kinds of handicapping conditions. 
Despite this progress, the percentage of handicapped children receiving an education is very limited.

Currently, the Malaysian government shows an increased consideration for providing public education for exceptional individuals. The federal government has taken over the responsibility of delivering education services for the blind and deaf. Education for these children is provided in residential schools and in segregated classes in regular schools. The federal government is also providing $90 \%$ of the salaries of teachers in ten schools for mentally retarded children and three schools for cerebral palsied children run by voluntary organizations. Additionally, the government has started two sheltered workshops for mentally handicappeã adults. Various authorities dealing with handicapped persons predict the government's complete takeover of the education and training of the handicapped population of Malaysia in the near future. In the event that public education for the handicapped becomes a priority for Malaysia, special education leadership personnel will be vital.

Leaders in special education will have an important role in planning and providing a healthy atmosphere that can nurture the development of handicapped individuals. Studies conducted in the United States show that knowledge of teachers' attitudes is Iundamental to the establishment of a program to increase the scope and range of education for the handicapped. It is also known that the success 
of education for the handicapped depends mainly on the attitudes and skilis of classroom teachers. Blackwell (1972), Dunn (1968), Johnson (1962), and Jacobson (1960) have theorized that attitudes influence behaviors of teachers and consequently affects the mental and psychological development of students.

Anderson (1964) pointed out the importance of a healthful school environment and the emotional atmosphere created in the school. According to Anderson "the most important thing in the environment is people and the most important person is the teacher" (p. 431). Haring, Stern, and Cruickshank (1978) stressed that knowledge of teachers concerning handicapped children has a potent influence on the social and emotional adjustment of these children. Yuker (1965) indicated that psycho-social barriers may be as handicapping to the disabled as physical limitations and architectural barriers. A study by Moffit (1932) showed the extent to which the teacher can produce an accepting atmosphere for the disabled. He found that almost one-fifth of more than 600 students in his study attributed the cause of their prejudice against certain races to the instruction delivered at school. Conine (1968) suggested that the unfavorable attitudes of the public toward disabled persons may reflect the reactions of prejudiced school teachers.

If handicapped children are to spend a significant portion of their time in the school environment, the 
attitude of those who create that environment must be positive and accepting. Realizing the importance of teachers' attitudes toward disabled students' self-concept and academic performance, many attitudinal studies have been performed in the United States. Such research results have served as an empirical basis for teacher training and program development. But, no attitudinal studies have been conducted in Malaysia. Therefore, there is a great need for the study of educators' attitudes toward the handicapped in Malaysia.

\section{Statement of the Problem}

This study measured the levels of acceptance or rejection of handicapped children by elementary schoolteachers and administrators (principals) in Malaysia in relation to demographic and experiential variables. Based on the result of the study, recommendations for educating school personnel and planning programs for the education of the handicapped have been suggested. More specifically, the study has addressed the following questions:

1. Is there a difference in attitudes of teachers based on demographic variables such as sex, age, and race?

2. Is there a difference in attitude between teachers and administrators?

3. Does contact with handicapped persons, level of education, number of years teaching, and attendance in 
workshops or conferences influence the degree of acceptance or rejection of hanaicapped individuals?

4. What are the levels of attitudes of elementary schoolteachers and principals toward handicapped individlials when measured by the Attitude Toward Handicapped Individuals Scale?

5. If there are differences in attitudes of educators in Malaysia based upon demographic and experiential variables, what are some ways to improve attitudes and to educate people about handicapped persons?

6. Do teachers and administrators have a preference for a particular category of handicapped individuals?

\section{Statement of Hypotheses and Rationale}

This study measured the levels of acceptance or rejection of handicapped individuals by elementary schoolteachers and administrators in Malaysia. Studies carried out in the United States indicated that there is a relationship between demographic and experiential variables and attitudes toward handicapped individuals. Thus, in order to obtain a more meaningful picture of the attitudes of teachers and administrators, the following hypotheses were tested at the .05 level:

Ho:1. There is no significant difference between the mean scores of respondents grouped according to attendance at conferences or workshops or other related presentations dealing with special education. 
Ho:2. There is no significant difference between the mean scores of respondents grouped according to the degree of contact with handicapped people (family, friend, student, neighbor, or none).

Ho:3. There is no significant difference between the mean scores of respondents grouped according to the years of teaching experience.

Ho: 4. There is no significant difference between the mean scores of respondents grouped according to the level of education (school certificate and teacher training, higher school certificate and teacher training).

Ho:5. There is no significant difference between the mean scores of teachers and administrators.

Ho:5. There is no significant difference between the mean scores of male and female respondents.

Ho:7. There is no significant difference between the mean scores of respondents grouped according to age categories.

Ho:8. There is no significant difference between the mean scores of different races (Malay, Chinese, Indian, or other).

Hypotheses regarding differences in responses to individual items on the attitude scale and the survey will be investigated. 


\section{Definition of Terms}

1. Attitude--The term attitude indicates a predisposition to think, perceive, and behave toward a cognitive object (Kerlinger, 1964).

2. Attitude scale--This term refers to a scale designed to assess an individual's feelings and tendencies toward action with respect to social situations, objects, or people.

3. Early intervention--This term refers to all efforts made on behalf of handicapped children for preventing, remediating, or compensating their disability before they reach the age normally expected for beginning preschool.

4. Handicapped individuals--Handicapped individuals are those who are evaluated as being mentally retarded, deaf, blind, emotionally disturbed, and individuais who are having specific learning disabilities, who, because of the impairments, need special education.

5. High-risk children--This term refers to children "who for socioeconomic, health, or genetic reasons, face developmental delay" (Haring, 1978, p. 55).

6. Mainstreaming--This term refers to the temporal, social, and instructional integration of exceptional children with normal peers. It is based on an ongoing individually determined educational needs assessment, requiring classification of responsibility for coordinated 
planning and programming by regular and special education administrative, instructional, and supportive personnel.

7. Malay medium schools--This term refers to all schools in which instruction is delivered in Bahasa Malaysia (Malay), the national language of Malaysia. In Malaysia, medium of instruction is often referred to as the language of instruction. Malay medium schools are public schools and the primary provider of education for the country.

8. Negative attitude--This term refers to social or occupational rejection or nonacceptance of the disabled and hostility or aggressiveness toward disabled individuals (Donaldson, 1974).

9. Positive attitude--This term indicates less stereotyping of the disabled as a stigmatized group and/or less unpleasant feeling or reactions toward the disabled (Yuker, Block, \& Younng, 1966).

10. Resource teacher--This term refers to "a special teacher who works in a resource room where handicapped pupils come for specific individualized instruction. This specialist also serves as a consultant to regular classroom teachers and suggests methods and materials to those working with children who have learning problems" (Mandell \& Fiscus, 1981, p. 490).

11. Special education--This term refers to the instruction designea for the unique characteristics of children who 
have needs that cannot be met by the standard school curriculum.

\section{Significance of the Study}

Various studies on teacher attitude toward the handicapped in the United States have indicated that it is vital to measure teachers' and administrators' attitudes toward the handicapped since the attitudes influence the value system of future generations. Such studies have served as an empirical basis for teacher training programs and program development for the handicapped. As described in the background of the problem, special education for the handicapped in Malaysia is in the beginning stage.

Malaysian studies of attitudes toward the handicapped are new. Thus, there is a need for basic research to formulate theories. The significance of this study lies in its contribution to the construction of basic theories and suggesting recommendations for teacher training programs and special educational program development.

\section{Assumptions of the Study}

1. It is assumed that teachers and administrators will make an earnest attempt to answer the questionnaire thoughtfully and honestly.

2. It is assumed that the opinionnaire will be filled out by the teachers and administrators independently, without consultation with other teachers and administrators. 
3. It is assumed that the opinionnaire covers all relevant areas regarding attitude toward handicapped children.

4. It is assumed that the selected sample is a true representation of the population under study.

\section{Limitations of the Study}

1. Teachers and administrators in private schools (Chinese medium, English medium and Tamil medium schools), and secondary schools (junior high and high school) are not included in this study.

2. Although the selection of the sample is randomized, the results may not be generalizable to other states and schools.

3. Only one paper and pencil self-rating instrument is used in this study. Since, attitudinal scales tend to measure verbal behavior rather than the actual demonstration of behavior, the extent of the interpretation of attitudinal measure is a limiting factor. 
CHAPTER II

REVIEW OF THE LITERATURE

\begin{abstract}
Studies of teachers' attitudes toward the handicapped have been of great concern to researchers in the field of education in the United States. Various methods and techniques have been used in assessing attitude toward handicapped individuals. But, attitudinal studies are totally new in Malaysia. As a result, it was necessary to seek research conducted in the United States with the belief that it would serve as a theoretical basis for the proposed study. Also, it was brought to the writer's attention that attitudinal studies carried out in developing Asian countries would be worthwhile to be examined. Thus, the review of literature is concerned with four separate issues: attituainal scales, attitude toward the handicapped in the United States, methods for attitude modification, and attitude toward the handicapped in Malaysia and other developing Asian countries.
\end{abstract}

\title{
Attitudinal Scales
}

Since the late 1920 s many attempts have been made to construct valid attitudinal measures. The three attitudinal scales widely used at present are Likert-type scales, 
equal-appearing scales, and cumulative or Guttman scales. Likert-type rating scales appear to be the most popular technique.

Attitude Toward Disabled

Persons Scale (ATDP)

Yuker et al. (1966) published the original Attitude Toward Disabled Persons (ATDP) scale. This is a Likerttype scale developed to measure attitude toward disabled persons in general rather than attitudes toward specific disability groups, and to measure both the attitudes of disabled persons and the attitudes of nondisabled persons. The ATDP is probably one of the best known and most widely used instruments for attitude measurement (Horne, 1978). In developing the ATDP, the authors defined the term disabled as including any person with a handicapping condition. There are three forms for this scale. Form-0 contains 20 items and Forms $A$ and $B$ each contain 30 items. The subjects rate each item on a six-point scale:

$$
\begin{array}{ll}
+3 & \text { I agree very much } \\
+2 & \text { I agree pretty much } \\
+1 & \text { I agree a little } \\
-1 & \text { I disagree a little } \\
-2 & \text { I disagree pretty much } \\
-3 & \text { I disagree very much }
\end{array}
$$

Scoring procedures result in a single total attitude score. Numerous investigations of the reliability and validity of the scale show that the measure is reliable and valid. 
Reliability of ATDP. The reliability of ATDP has been tested by test-retest, split-half, immediate equivalent forms, and delayed equivalent form methods. Twenty-three reliability studies have been reviewed by Yuker, Block and Younng in which the test-retest and split-half methods were used with various groups of subjects, totaling approximately 2,500, responding to ATDP (Yuker et al., 1966). The coefficients obtained have ranged from +.66 to +.89 and +.75 to +.85 for each method respectively, with a median of +.73 .

Validity of ATDP. Construct validity was chosen as the method of validation for the ATDP. Construct validity is used when the tester has no criterion measure of the quality with which he or she is concerned. In this case, an indirect measure must be used by integrating evidence from many different sources. The validity of the ATDP was demonstrated in terms of substantial interrelationship between ATDP scores and other measures of behavior. Validity of the scale was examined by the developers in relation to disabled subjects and nondisabled subjects separately. It was assumed that when a disabled person responded to the items in the instrument, he/she would identify with the concept "disabled person" and might provide a measure of acceptance of disability and selfacceptance. But when ATDP was administered to the nondisabled, it was assumed to measure attitude toward 
disabled persons in terms of a stereotype group who are different from everybody else.

In order to validate the instrument with nondisabled persons, it was predicted in general that: (a) nondisabled persons probably would be less accepting of disability than disabled persons; (b) the scores of the ATDP would be positively related to the amount of contact with the nondisabled person; and (c) on the basis of other measures of behavior, nondisabled females would tend to be more accepting than nondisabled males. The results of the data obtained in order to substantiate the above predictions confirmed them at the $.001, .001$, and .05 levels of confidence respectively.

For further validation of the scale, the developers of the scale measured it for the test taking attitude of responding dishonestly, responding in a socially desirable way, and for the tendency to endorse test statements. It was found that these were not significant components of responses on the ATDP.

Attitude Toward Handicapped Individuals Scale (ATHI)

The Attitude Toward Handicapped Individuals Scale (Lazar, 1973) is a modification of the ATDP Scale. The ATHI has substituted the term "hanaicappea" for the term "disabled." A detailed description of the ATHI, which is the scale utilized for this study appears in the Description of Instrumentation in chapter III. 
Attitude Toward the Handicapped

in the United States

Present trends in the education of handicapped children in the United States have prompted educators to provide many such children with part-time and/or full-time educational programs within the structure of public day schools (Haring et al., 1978). Within such structures, attitudes of regular classroom teachers toward handicapped children are of vital importance. Research findings have generally demonstrated stereotyped attitudes of the general public toward the disabled (Nooman, 1967). Studies on attitudes of various professionals working with the disabled have indicated that attitudes of teachers may not be different from those of the general public (Bell, 1962; Haring et al., 1978; Panda \& Bartel, 1972). Conine (1968) found on a questionnaire checklist that elementary schoolteachers were neither accepting nor rejecting of disabled persons, but concluded that unfavorable attitudes of the public toward disabled persons may reflect, at least in part, the reactions of prejudiced schoolteachers.

Woody (1974) investigated administrators' attitudes toward the handicapped by using the Attitude Toward Handicapped Individuals Scale (ATHI). The variables used in the study were school grade levels (elementary, junior high, and high school), age, and experience with the handicapped. Analysis of responses on the ATHT Scale indicated no significant differences on scores among 
principals at three school grade levels in their attitudes toward the handicapped. Also, the data did not show any significant differences in the degree to which the experienced and nonexperienced principals perceived the handicapped.

Smith, Flexer, and Singleman (1980) attempted to assess the attitudes of secondary school principals toward mentally retarded pupils, learning disabled pupils, and work-study programs. Survey materials which were mailed to the potential subjects included background information items, three semantic differential scales, and a scale to assess opinions of work-study programs, and associated relationships to disability issues. Results indicated that attitudes toward mentally retarded pupils were significantly less positive than those toward nondisabled pupils. In addition, it was found that there was a significant correlation between principals' attitudes toward disabled pupils and their work-study program.

Gibson (1980) studied administrators' attitudes toward handicapped individuals and toward mainstreaming. He collected data by using the ATHI scale. The variables in his research included sex, service as an administrator, teaching experience, and age. No significant relationship between the variables were found on the scale measuring attitude toward the handicapped. However, Gibson found that administrators possessed positive attitudes toward handicapped individuals and toward mainstreaming. 
Morton (1978) investigated the effects of several demographic variables and of two types of interventions on the attitudes of students majoring in higher education administration toward disabled persons and toward the provision of special services for disabled stuảents. Data obtained by the ATDP Scale and the Value of Special Services (VSS) scale indicated that students had generally positive attitudes toward disabled people and that demographic and intervention variables had little effect on these attitudes. Similarly, demographic variables had little impact on attitude toward the provision of special services. It was also found that disability simuiation and provision of information had a strong impact on increasing positive attitudes toward the provision of special services for disabled students.

Davis (1981) examined the perceptions of public school principals on the most effective placement for mildly and moderately handicapped pupils within their buildings. The subjects were 345 principals from public elementary and secondary schools. The principals Attitude Toward Mainstreaming and Related Training Scale was used to measure their attitudes. It was found that $82 \%$ of the principals considered a combination of regular class and part-time special education class as the most effective method of education.

Payne and Murray (1974) conducted a survey to evaluate the attitudes of elementary school principals toward 
integration. The subjects were 50 suburban school principals and 50 urban school principals. The questions included information on principals' willingness to integrate handicapped children into their regular programs and categories of handicapped children they would be willing to include in the integrated classes. The results indicated that urban elementary school principals were more reluctant to integrate handicapped children than their suburban counterparts.

Murphy (1960) surveyed 100 elementary school principals to determine if they had preferences concerning the types of handicapped children they teach. Results indicated that the first preference by both principals and teachers was for the gifted group and the least preference was for the mentally retarded group.

Smith (1979) surveyed 200 regular classroom teachers, 75 special education teachers, and 50 principals randomly selected from three large school districts to determine their preference for the categories of exceptional students to be mainstreamed or not to be mainstreamed. The categories included borderline and educable retarded, trainable retarded, learning disabled, enotionally handicapped or behavior disordered, hearing impaired, visually impaired, physically handicapped, health impaired, and speech impaired. The data revealed that the principals were more favorable toward mainstreaming borderline and educable retarded groups. It was also found that all respondents 
were strongly against mainstreaming the trainable mentally retarded group. Smith recommended an inservice training for teachers who were not in favor of mainstreaming. Gozali (1971) studied 266 subjects ranging from 12 to 60 years old using the ATDP Scale. He reported a positive correlation between age and the scores on the ATDP. He found that the subjects increased acceptance until the age of 51 and then the correlation decreased with the subjects becoming less accepting than the younger respondents.

Harasymiw and Horne (1976) administered an attitudinal instrument to 352 teachers from integrated and nonintegrated school districts. The results showed that teachers from integrated schools had more favorable attitudes. They also analyzed the effect of sex, and age. No significant differences were found between the attitudes of males and females. But their data showed that younger teachers were more favorable towards the handicapped.

Gottlieb and Corman (1975) conducted a survey to examine positive stereotypes, segregation in the community, segregation in the classroom, and perceived intellectual and physical handicap. A questionnaire was completed by 430 adults who were randomly selected and randomly stratified by sex, and age. Ninety percent of the total number of the sample were teachers. Factor analysis of the data revealed that inclusion of handicapped children in regular classrooms would not harm nonretarded children and that integration would benefit retarded children. These results 
also indicated that younger respondents, especially those between 20 and 30 expressed more positive attitudes than older respondents. Similar findings were reported by Hollinger and Jones (1970) who used a social distance scaie to measure attitudes of the general population toward the handicapped. Gottlieb and Corman's (1975) data did not support the commonly held notion that women hold more favorable attitudes than men toward the handicapped. Brooks and Bransford (1971) stated that teachers do have a stereotypic and negative attitude toward the handicapped and they need to undergo special training to develop a positive attitude toward the handicapped. Information received by Brooks and Bransford from the University of New Mexico Institute revealed that "from knowleage comes understanding and from understanding comes acceptance" (p. 259).

Kaufman (1977) investigated the effect of training regular classroom teachers to increase their knowledge of and improve their attitude toward educable mentally retarded (EMR) pupils. The subjects were randomly assigned to one of four treatment conditions including a three-hour workshop providing information about EMR children, a threehour workshop providing contact with EMR children, a three-hour workshop providing both information and contact, and a control group with no contact or workshop. The results showed that teachers who received information about EMR pupils scored higher on knowledge measures than those 
who had not received information. In addition, those who had contact during the workshop with EMR children scored higher than those who had no contact.

A survey by Larivee (1981) showed that increased experience and contact with exceptional children would increase teachers' positive attitudes toward the handicapped.

Foley (1978) investigated attitudes of teachers towards the handicapped and their placement preferences for exceptional students by a survey in which an attempt was made to relate attitudes toward disabled people as measured by the ATDP Scale, the Attitude Toward Educational Mainstreaming, and demographic characteristics of teachers' age, sex, teaching level, amount of experience with disabled children, and number of courses taken related to disabled children as measured by a personal data questionnaire. The results indicated there were no significant relationships between attitudes and demographic characteristics; however, differences in placements for particular students based on teacher demographic characteristics were noticed. The placement differences by the teacher demograpinic group were affected by the nature and extent of the child's disability.

Kennon and Sandoval (1978) studied teacher attitudes held toward educable mentally retarded children. Sixty experienced majority and minority EMR arid regular classroom teachers as groups completed the Multidimensional Attitude 
Scale on Mental Retardation. They found that EMR and regular class teachers did not differ in their attitudes toward retarded people. Analysis of variance revealed ethnic group differences in certain areas of attitudes within the regular class teachers and EMR class teachers. It was also found that regular class teachers with previous experience with retarded pupils were more favorable toward them than teachers with Iittle contact with EMR chilaren and adults.

Proctor (1967) investigated classroom teachers' attitudes toward integrating handicapped children into regular classrooms and related this to knowledge of and experience with handicapped children. She found that special class teachers were more realistic than regula: class teachers in their attitudes on integration. This finding was contrary to Comb and Harper (1967) who stated that greater experience helps a teacher to achieve a more realistic attitude toward educational placement of handicapped children. This supports the suggestion of Haring et al. (1978) that orientation programs designed \pm 0 develop knowledge and understanding about children are an effective approach in improving classroom integration for exceptional children.

Several studies have been carried out to examine if there was a preference toward various categories of exceptionalities. Kingsley (1967) surveyed 223 elementary and secondary education major students to determine which 
type of exceptionality they preferred to work with the most and the least. The category least preferred was the severely retarded and the most preferred was the gifted. Shotel, Iano, and McGettigan (1972) found teachers in their study preferred learning disabled children to emotionally disturbed and felt least favorable toward the educable retarded.

Sipperstein and Gottlieb (1978) surveyed the attitudes of parents and teachers toward mildly and severely retarded children. The subjects included 74 women who had some prior experience with disabled children. Twelve of the items dealt with community integration and 13 dealt with school integration. Overall, the subjects indicated significantly more positive attitudes toward mildly retarded chilaren than toward severely retarded children. Discriminant analysis showed that the differences in attitude toward the two groups related to school and not to community integration. It was also found that the subjects were highly supportive of regular classes for mildly retarded children, but not generally supportive of regular classroom integration for severely retarded children.

Williams (1977) assessed the attitudes of regular classroom teachers toward the mainstreaming of disabled students. The subjects in his study were elementary schoolteachers who responded to a questionnaire specifically designed for the study. The attitudes toward educable mentally retarded children, learning disabled children, 
physically handicapped children, and socially and emotionally disturbed children were assessed. The teachers were asked whether each category should be mainstreamed, if they felt capable of teaching each category, and if they would voluntarily mainstream each category. The results showed definite differences in acceptance of categories with teachers indicating most willingness to mainstream physically handicapped students, and least to educable mentally retarded students. In addition, differences in degrees of acceptance were related to contact variables such as experience in teaching disabled children, training in disability, and presence of disabled friends or relatives.

Moore and Fine (1978) conducted a study which investigated attitudes toward mainstreaming and compared descriptions of a hypothetical and "normal" child by 22 regular classroom and 39 special education teachers. The special education teachers were more accepting of mainstreaming children with retardation and disability, and all groups supported mainstreaming the child with a learning disability more than the child with mental retardation. The researchers concluded that distinct stereotypic images of disability existed within teacher groups.

The influence of labeling has been investigated by several researchers. Foster and Keech (1977) inäicated that teachers hold negative expectations toward labeled 
children. Based on this, they stressed that teachers will have a negative attitude toward the handicapped. This is in agreement with warren, Turner, and Brody's (1967) finding that attitudes of student teachers toward brain injured and mildly and severely retarded children did not change in a positive direction, but instead, it became more negative in some cases.

Fine (1967) found certain differences between regular and special class teachers that seemed psychologically relevant. Regular class teachers placed less emphasis on personal and social adjustment factors, but were more demanding than special class teachers in encouraging the low ability child to try harder.

A comparative attitudinal study of regular and special teachers was conducted by Flynn (1978) using a survey questionnaire with 16 special class and 35 regular class teachers. Results indicated that special education teachers' expectations for the handicapped were superior to the expectations of regular education teachers.

Rosenthal and Jacobson (1968) investigated the effect of teacher expectation on students' academic performance. In their study, teachers were told that some of their students had the potential for considerable academic improvement by the end of the year. Even though students in the study were selected randomly, it was found that the children who were expected from the teacher to make academic progress gained academic improvement as expected. 
Schemelkin (1981) carried out a survey of regular education teachers' and special education teachers' attitudes toward mainstreaming. He found that regular education teachers showed a more positive attitude toward the handicapped and they favored integrating handicapped children with nonhandicapped children.

Barngrover's (1971) study indicated that nearly half of the educators she interviewed favored regular class placement for the handicapped children. Hudson, Graham, and Warner (1979) conducted a survey study to determine the attitudes and needs of regular classroom teachers toward mainstreaming. A questionnaire was completed by 151 regular elementary schoolteachers from 28 school districts in two states. The results from the questionnaire suggested that the attitudes of regular classroom teachers were not in support of mainstreaming the handicapped children. The teachers expressed the need for additional time and special training in educating the handicapped.

Gullotta (1974) studied teacher attitude toward moderately disturbed children by presenting case histories to 50 teachers. The subjects answered a questionnaire on a likert seven-point scale. An analysis of Gullotta's data revealed that teachers have the attitude that as long as they are provided with the necessary support needed to maintain and help disturbed children, they are willing to keep the children in the classroom. 
Newman (1976) undertook a study to obtain information about attitudes of university faculty toward the admission of the handicapped. This study revealed that virtually 98\% were in favor of admitting handicapped students at least on a restricted basis. Regardless of the source of their opinions, the faculty expressed both a willingness to participate in an effort to accommodate handicapped students and an openness to working with students whom they knew would present difficult problems.

Fonosch and Schwab (1981) studied the attitudes of selected university faculty members toward disabled students by using the Attitude Toward Disabled Persons Scale. Although the faculty members generally held positive attitudes toward integrating disabled students into college classrooms, highest scores were exhibited by faculty who had previous contact with disabled persons, female instructors, and faculty members in education and social sciences.

\section{Methods for Attitude Modification}

Donaldson (1980) stressed the importance of analyzing the factors which produce positive attitude change. He added the importance of investigating theoretical bases which would be helpful in explaining the success of such interventions.

Leyser, Abrams, and Lipscomb (1982) conducted an investigation to evaluate the impact of a preservice 
teacher training program on the attitudes of prospective regular classroom teachers toward mainstreaming. Their study included one experimental group and two control groups. The experimental group was involved in a variety of mainstreaming activities which included courses on the handicapped child in the regular classroom and practical experience in which students were introduced to a variety of settings where handicapped children and youth were educated. They also had the opportunity to listen to several guest speakers from different schools of thought, such as psychologists, regular educators, and university professors. The Inventory for Measuring Attitudes Toward Mainstreaming was used as the pretest and posttest. Data were analyzed by one-way analysis of variance on both pretest and posttest. The findings revealed strong evidence for the usefulness of a preservice teacher training in modifying attitudes toward mainstreaming. The researchers emphasized the need to offer teachers as well as other school personnel additional training in the form of courses, workshop seminars, practica, and experience to work with handicapped pupils.

Donaldson (1974) conducted a study for assessing the effects of different modalities on attitudinal change toward physically disabled persons. Ninety-six students were randomly assigned to either a (a) live, (b) video, (c) audio, or (d) control group. Each group had 15 males and 15 females. The ATDP was used as the pretest and postest. 
Live, video, and audio presentations of a 50-minute discussion of issues ana problems related to physical disability by a panel of six disabled young adults were presented to the experimental groups. The data showed that both the live and videotape presentations were effective in modifying attitudes toward disabled persons. But the audio presentation did not have any significant effect on the attitudes of the subjects.

Ozyurck (1977) partially replicated Donaldson's (1974) study to assess the extent of modification of prospective Turkish teachers' attitudes toward disabled persons after participating in varied presentations of a panel discussion of physical disabilities by a group of well adapted Turkish individuals with visible physically disabling conditions. The varied presentations included live, audio, and printed treatments. The subjects were 93 third and fourth year students majoring in elementary education at the Ankara Teacher Training School for elementary education in Turkey. The subjects were assigned randomly to three experimental and one control group. The first experimental group was presented with a videotape of a group of disabilities and related topics. The second group attended a live session of a similar group discussion on handicaps, and the third group was exposed to an audiotape with a discussion on handicaps. The Attitude Toward Disabled Persons Scale and the Intensity of Attitude scale were given to all subjects as pretest and posttest. It was 
found that all of the procedures modified the subjects' attitudes positively toward the physically disabled.

Aukayanagul (1979) studied the attitudinal change of nondisabled Thai students toward the physically disabled resulting from live, video, audio, and printed material presentations of a panel discussion of physical disabilities by a group of physically disabled. The subjects included 200 Thai students. They were pretested and posttested by the ATDP Scale. The video, audio, and printed material presentations of the discussion of physical disabilities did not produce any attitudinal change toward physically disabled individuals. However, the live panel discussion was found to be effective in changing attitude in a positive direction.

Haring et al. (1978) conducted a workshop to modify teachers' attitudes toward the handicapped. The workshop included a one-hour lecture first; in the second hour the subjects were divided into smaller groups for free discussion under the direction of discussion leaders. During the discussion period, the teachers were encouraged to verbalize any misinformation, misunderstanding, or negative attitudes which they might have had. Fifteen discussions were held over a period of 30 weeks. The subjects were pretested and posttested by the General Information Inventory. The analysis of data using a matched pair $\underline{t}$ test showed a significant increase in positive attitude. 
Dailey and Halpin (1981) carried out an experimental study for modifying undergraduates' attitudes toward the handicapped by videotapes. Fifty-two special education and nonspecial education majors enrolled in an introductory special education course were randomly assigned to either an experimental group that viewed videotapes of handicapped children or a control group that did not. The pretest and posttest measures used were the ATDP and the Special Vocational Needs Attitude Scale (SVNH). The data on the ATDP indicated a significantly more positive attitude toward the handicapped. A significant interaction of treatment and academic major on attitude toward the handicapped measured by the SVNH showed that the treatment was differentially effective for special education majors and nonspecial education majors. The authors concluded that regardless of academic major, videotapes of handicapped children should be used in conjunction with an introductory special education course for the positive modification of generalized attitudes toward the handicapped.

Naor and Milgram (1980) compared the effects of traditional and experimental instructional programs on undergraduate women in preservice education classes devoted to improving attitudes toward and knowledge of mentally retarded, emotionally disturbed, learning disabled, and physically handicapped individuals. Traditional methods included lecture and discussion whereas 
experimental methods included lecture, discussion, and field trips. Both programs were found to be successful in improving attitudes. But the experimental programs showed advantages over the traditional program in the areas of attitudes and behavioral intentions.

Rhoads (1978) studied the effect of role-playing modeling techniques in changing attitudes of teacher trainees enrolled in special education courses. She collected data by using the Minnesota Teacher Inventory. The analysis of data of pretest and posttest using a $t$ test indicated : significant increase in positive attitudes. McDanniel (1982) investigated the attitude change of teachers in a preservice and inservice workshop. She used a multiple regression analysis to examine the relationship between variables of sex, age, educational background, and number of years of teaching experience and found that none of these variables were significant in predicting posttest scores. There was no significant difference between the groups on the pretest using a one-way analysis of variance. But when the posttest was analyzed by using a dependent $\underline{t}$ test, it indicated a gain in positive attitude.

\section{Attitude Toward the Handicapped in Malaysia}

This researcher's experience suggested that regular education teachers in Malaysia exhibit certain stereotypic negative attitudes toward those who deviate from the normal in terms of physical appearance, academic ability, 
and/or socialization skills. But this assumption cannot be substantiated through Malaysian literature because of the scarcity of documented research. However, a brief description of special education status in Malaysia is considered important and is cited below.

As explained in the first chapter, the school age population between the ages of 5 and 18 in Malaysia is $2,507,665$. Within this population, $6.4 \%$ is estimated to have some kind of disability (see, 1983). While $98 \%$ of the normal children attend school, only $2 \%$ of the handicapped population have the opportunity to attend school due to the lack of special education facilities in Malaysia (See, 1983).

The handicapped individuals enrolled in various schools include hearing impaired, visually handicapped, mentally retarded, and cerebral palsied. Chua (in see, 1983 ) described special education as a recent phenomenon in Malaysia. The hearing impaired children and the visually handicapped children were the first categories of handicapped pupils to receive educational attention in Malaysia. Presently, 1,635 hearing impaired individuals attend school. Of these, 509 students are at the secondary level (junior high and high school). There are 262 visually handicapped students, of whom 176 are at the secondary level and ten are at the higher secondary level (Chua in see, 1983). 
There are no documented statistics on the number of handicapped persons in each category of disabilities in Malaysia. Special education programs for the blind and deaf are conducted by the Ministry of Education in segregated schools and in special classes in few regular schools. The programs for mentally retarded children and cerebral palsied children are undertaken by voluntary associations which are partially supported by the Ministry of Education and the Social Welfare Ministry.

About 212 mentally handicapped adults of 18 years and above receive vocational training in a residential school for handicapped people in Tampoi, Johore, one of the states in Malaysia. This residential school is supported by the Social Welfare Ministry. There are four voluntary associations which run day schools for mentally handicapped children and two voluntary associations offering programs for cerebral palsied children. The number of mentally retarded children attending school is 542, while the number of cerebral palsied children attending school is 264. A few regular schools in selangor offer segregated classes for a limited number of slow learners. However, there is an absence of special educational programs for learning disabled and emotionally disturbed individuals. often learning disabled chilaren are misunderstood and are neglected in the mainstream without any special assistance in their instruction. Also mildly mentally 
handicapped pupils are very often treated in the same way as the learning disabled children in the mainstream. The majority of the teachers employed in the above mentioned special schools lack formal special education training. According to Chua (in see, 1983), special education teachers for the blind and deaf were trained in Western countries, mostly England, until 1962, when the Education Ministry began to train its own teachers in Malaysia. But teacher training facilities for mentally retarded children, learning disabled children, and emotionally disturbed children are nonexistant in Malaysia.

Special Education in other Developing Asian Countries

The writer was able to obtain information on limited research related to special education issues conducted in other Asian countries and these are described here.

Based on information supplied by the First Asian Conference on Mental Retardation in Tokyo in 1975, Burgner (1977) reported the status of special education services for mentally handicapped individuals in Asian countries. She emphasized that special education in Asian countries is significantly underdeveloped.

A pioneering study on the attitudes of teachers and students majoring in eaucation, as well as students with other majors, was conducted by Kasiwat in 1975 in Thailand. She stated that there were no studies concerning attitudes toward handicapped persons in Thailand. The Attitude 
Toward Disabled Persons Scale translated into Thai language was used to measure the subjects' attitude. The data revealed that the ATDP mean scores of teachers were more positive than students majoring in education. There was no significant difference in attitudes based on age, sex, amount of educational background, and previous exposure to handicapping conditions.

Sen (1975) reported there were no statistics in India regarding the incidence of mental retardation. He attributed this to the shortage of funding and lack of trained personnel to conduct surveys. However, he indicated that according to the World Health Organization, about $4 \%$ of the Indian population are mentally retarded. Also, sen pointed out that there were no extensive studies available in the field of mental retardation. From that report it is assumed that no attitudinal studies toward the handicapped have been conducted in India.

Jordan (1968) conducted a cross-cultural study on 11 nations on attitudes toward education and physically disabled persons. His subjects included a special education and a rehabilitation personnel group as well as a secondary and an elementary regular teacher group. He reported similar attitudes among matched teacher role groups across nationalities, i.e., young Japanese teachers to young American teachers.

A cross-cultural study of Japanese and American teachers by Sato (1980) showed a nonsignificant difference 
based on demographic variables, and special education teachers versus regular class teachers and principals. Mia, Islam, and Ali (1981) studied the magnitude of the problem of disabled children in Bangladesh and analyzed various factors related to their disabilities and the social cultural conditions that have a bearing upon their well-being. They also attempted to identify the limits of the existing institutional facilities for disabled children. The data on family attitudes toward handicapped children were found to be influenced by a supernatural explanation of disability rather than by rational understanding of the problem. The study revealed that programs and research were underdeveloped and research stuaies on educators' attitudes toward the handicapped were nonexistent in Bangladesh. Similarly, a United Nation's stuay by wong and Tompar-Ties (1981) on community programs in the Philippines for the handicapped showed that althongh $21 \%$ of the children aged 0-6 were handicapped, existing programs were limited and there were no reported studies on attitudes toward handicapped people.

\section{Summary of the Review of the Literature}

The review of the literature was mainly concerned with four issues: attitudinal scales, attitude toward the handicapped in the United States, methods for attitude modification, and attitude toward the handicapped in Malaysia and other developing Asian countries. 
Attitudinal scales widely used were reviewed. The three scales normally used were found to be Likert-type scales, equal-appearing scales, and cumulative or Guttman scales. Likert-type scales were found to be the most popular technique for measuring attitudes.

Several studies reviewed on the effect of age, sex, race, contact, experience with the handicapped, and educational background revealed conflicting results. Generally, it was found that demographic variables did not have significant effects on attitudes. But, teachers and principals who had special educational background, contact with the handicapped, and experience with handicapped people showed more favorable attitudes toward handicapped individuals. Studies indicated that regular education teachers and principals showed increasingly favorable attitudes toward mainstreaming the handicappea. There did not seem to be much difference between principals' and teachers' perceptions toward handicapped individuals. In fact, it was found that they were in close harmony with their attitudes.

Different techniques on modifying attitudes were discussed. The reviews indicated that video presentations on handicappism had a great degree of effect on changing attitudes in a positive direction. Preservice and inservice training experiences produced positive attitude growth.

\footnotetext{
It was found that a hierarchy of preference toward disabilities existed among educators. Among the
} 
exceptionalities, gifted children were the most accepted group; this group was followed by learning disabled children, physically handicapped children, and emotionally disturbed children, with the least preferred identified as mentally retarded children.

A review of the special education status in Malaysia indicated the inadequacy of educational facilities for the handicapped population and the absence of attitudinal research. Due to the lack of Malaysian teacher attitudinal studies, the writer cited available research concerning the education of handicapped children in other Asian countries.

The available Asian studies revealed that Asian countries are significantly underdeveloped in the field of special education. Two of the reasons for the scarcity of literature in special education were found to be lack of budget and trained personnel. 


\section{CHAPTER III}

RESEARCH DESIGN AND METHODOLOGY

This study attempted to assess the attitudes of Malay medium elementary schoolteachers and administrators (principals) toward handicapped individuals. Findings of this study provided a basis for making recommendations for a preservice and inservice teacher training program and overall program development for the handicapped in Malaysia. Survey research methods were used in this study in order to obtain the perceptions of Malay medium elementary schoolteachers and principals toward the handicapped.

\section{Selection of Schools and Sample}

A sample of Malay medium elementary schoolteachers and principals employed in the state of Selangor, Malaysia were selected for this study. The reason for selecting Selangor as the sample state was that, of the 14 states in the country, selangor is the most populous state. It also has a good cross-section of the various ethnic groups as well as both rural and urban dwellers. There are four types of schools in Selangor, Malaysia: Mixed races Malay medium schools, Chinese medium schools, 
Tamil medium schools, and Malay medium schools (for Malays only). Of the four types, Malay medium schools for mixed races were regarded as the most representative of the schools because various ethnic groups were best represented among these schools. A total of 30 elementary schools were randomly selected from a total of 116 Malay medium elementary schools. In order to achieve this randomization, a list of names of all Malay medium schools was obtainea from the Ministry of Education, Malaysia. The survey sample consisted of 450 elementary schoolteachers and 30 principals. Each of the selected schools had an enrollment of 20-28 teachers. The number of teachers selected randomly from each school was 15 and this randomization was obtained by using a table of random numbers. The determination of 15 teachers from each school was arbitrary. The names of the teachers were secured from their respective principals. Each school selected had one principal and the principal from each school was chosen as the sample.

\section{Description of Instrumentation}

The Attitude Toward Handicapped Individuals (ATHI) scale developed by Al Lazar was used as the survey instrument in this research. The questionnaire was translated into Bahasa Malaysia. The researcher obtained permission from the developer of the scale to translate and use it in this research. The reason for selecting this instrument was its proven validity in cross-cultural 
or international studies and its test-retest reliability. It has been used in more than 30 research studies--theses and dissertations.

Attitude Toward Handicapped

Individuals Scale (ATHI)

The Attitude Toward Handicapped Individuals Scale (Lazar, 1973) is a modification of Attitude Toward Disabled Persons scale, Form-0. The ATHI has substituted the term "handicapped" for the term "disabled." The substitution was made because the term "handicapped" was assumed to be more general in meaning, thus offering the opportunity to study attitudes toward all handicapped groups rather than only the physically handicapped. Both the ATDP and ATHI have the same number of items and are scored in the same manner. The subjects rate each item on a six-point scale:

$$
\begin{array}{ll}
+3 & \text { I agree very much } \\
+2 & \text { I agree pretty much } \\
+1 & \text { I agree a little } \\
-1 & \text { I disagree a little } \\
-2 & \text { I disagree pretty much } \\
-3 & \text { I disagree very much }
\end{array}
$$

The ATHI is scored by changing the signs of items $2,5,6$, 11, and 12 and totalling the 20 responses. After this calculation, the sign of the sum is changed and a constant of 60 is added (see Appendix E). The possible score range is from 0-120. A high score (above 70) on the ATHI indicates that the handicapped person is perceived to be quite 
similar to nonhandicapped persons, whereas a low score (below 70) indicates that the handicapped person is perceived as being "aifferent" from the nonhandicapped person. Each statement in the ATHI suggests that handicapped persons are either the same as or different from nonhandicapped persons. Approximately half of the items refer to similarities or differences in personality characteristics, and the other half deal with the question of special treatment for the handicapped.

A study to determine the relationship between the ATDP and ATHI revealed a significant correlation $(r=.80)$. A stability coefficient of .73 was obtained on test-retest of the ATHI (Stodden, Graves, \& Lazar, 1973). AlI correlations mentioned were significant at the .01 level (Lazar \& Denham, 1974; Sippel, Lazar, \& D'Alonzo, 1976; and Lazar \& Stodden, 1977).

\section{Administration of Attitude Toward Handicapped}

Individuals scale. The time required for administering the scale was estimated to be 15 minutes. Instructions for the respondent appeared on the top of the scale. In order to avoid any questions concerning the applicability or meaning of specific statements, the following statement was added to the instructions: "You may interpret the statements anyway you please, but respond to every item." Since this specific instruction was recommended by Yuker et al. (1966), developers of the ATDP Scale, it was believed by the 
researcher that the statement would not contaminate the validity of the ATHI.

Test battery. In order to investigate the various demographic and experiential variables, a simple questionnaire checklist was developed (see Appendix B).

In addition to the 20 questions in the ATHI Scale, two open-ended questions related to the topics listed below were included.

1. In order to understand the teachers' and principals' view of the type of education suitable for the handicapped, a choice of four types of delivery services was given (see Appendix B, Part II, \#1).

2. In order to determine the order of preference for working with the handicapped among teachers and administrators, the respondents were asked to rank the categories of handicapped individuals (Appendix B, Part II, \#2).

The general format of the ATHI scale used in this study was the same as the official version except that the questions were translated into Bahasa Malaysia, the national Ianguage of Malaysia. Since the researcher was unaware of the older respondents' fluency in Bahasa Malaysia, the English version of the scale was left in parentheses in order to avoid any question on clarity of meaning for the respondents. Statements on the personal data form also were written in English in parentheses. 
Validation of the Pranslation of the ATHI Scale into Bahasa Malaysia

The ATHI Scale was translated into Bahasa Malaysia in May 1982. The accuracy of the translation was established by mailing it to Malaysia and rechecking it by a certified Bahasa Malaysia teacher. It was then transiated back to English for determining its accuracy of meaning. As stated earlier in this chapter, the original or the English version of this scale was written in parentheses following each statement. This was done as a precaution to avoid any misunderstanding of the statement from the older respondents of this study as the researcher suspected the adequacy of the older respondents' fluency in Bahasa Malaysia.

Upon completion of the translation of the scale, it was necessary to validate the instrument with the Malaysian subjects of this study. The validation was established by administering it to 30 randomly selected Malaysians, including educators and lay people, during June 1982. The purpose of the initial administration of this scale among the 30 subjects was primarily to establish accuracy of the translation. Secondly, the validation was necessary in order to examine the Malaysian subjects' proficiency in answering the items on the ATHI scale.

As the researcher was unable to be physically present in Malaysia, a competent colleague, located in Malaysia administered the scale to those subjects. The subjects 
were asked to write their comments on the questionnaire and include any difficulties they experienced in understanding or interpreting the items on the scale.

The completed questionnaires were mailed back to the researcher in July 1982. The total score was computed for each questionnaire in order to determine the level of acceptance or rejection of the subjects toward handicapped individuals. All subjects scored less than 70 points on the scale.

The subjects reported discomfort with the mathematical concept used in the scoring procedure, i.e., +1, +2, +3, $-1,-2,-3$. As a result the scoring procedure was changed to $1,2,3,4,5,6$. It was noted that Lazar's latest edition of the ATHI scale uses the scoring procedure 1 , $2,3,4,5,6$, instead of $+1,+2,+3,-1,-2,-3$. But for the analysis of the data, the researcher had to change the scoring procedure to $+1,+2,+3,-1,-2,-3$ for computing the total score by using the scoring procedure described earlier in this chapter (see Appendix E). The two open-ended questions in the personal data form were pilot tested in December 1982 among ten Malaysian students enrolled at various universities in San Diego, California. The questions were completed by the respondents in the presence of the researcher. The questions appeared clear to the subjects. 
Procedures for Collection of Dissertation Data

A copy of the ATHI scale, the personal data form, and a copy of the cover letter were sent to the researcher's colleague in Malaysia with a request to make 480 copies of each form. It was necessary to obtain permission from the Ministry of Education, Malaysia, before the survey was distributed to the subjects. Thus, a copy of the ATHI Scale, the personal data form, a copy of the cover letier from the researcher describing the purpose of the study (see Appendix C) with a request that the survey be returned within ten days, and a copy of the permission letter from the Ministry of Education (see Appendix D) were sent to the randomly selected subjects during the last week of April 1983. Upon advice of the Ministry of Education. Malaysia, it was necessary for the researcher's colleague in Malaysia to collect the completed survey in person, ten days after it was sent. The advice for the personal collection of the completed data by the Ministry was to ensure the maximum return rate of the survey.

\section{Methods of Data Analysis}

The analyses of data were accomplished through use of the University of San Diego's Vax-11/780 computer and the SPSS Program. The test of significance between or among means was computed for each hypothesis. This was accomplished by using a computer program for the $t$ test 
and one-way analysis of variance. Hypotheses regarding

differences in responses to individual items on the ATHI

Scale were tested by chi-square.

The order of priority chosen by the respondents for

each definition category of handicapped-mentally retarded, deaf, blind, learning disabled, and emotionally disturbed was tabulated and the total number responding to each item was calculated for each category. The number of respondents who chose specific settings for the delivery of instruction was also calculated. 


\section{CHAPTER IV}

\section{ANALYSIS OF DATA}

This study was concerned with the population of all Malay medium elementary schoolteachers and administrators (principals) in the state of Selangor in Malaysia. The sample for this survey was randomly selected from a population of elementary schoolteachers and administrators. During the first week of April 1983, a test battery consisting of the Attitude Toward Hanaicapped Individuals Scale and a questionnaire checklist was mailed to the researcher's colleague in Malaysia. The test battery was sent to the selected schools by the colleague in the last week of April. The survey examined the levels of acceptance or rejection of disabled persons by elementary schoolteachers and principals plus tested eight hypotheses pertaining to possible relationships between the levels of attitudes and demographic and experiential variables.

\section{Presentation of the Data}

Of the 480 questionnaires delivered, 440 questionnaires were returned to the researcher's colleague in Malaysia by May 10, 1983. Ali completed forms were received by the researcher in the United States on May 28, 1983. Table 1 
provides a summary of the total sample of responses received from the educators.

\section{Table 1}

Number and Percentage of Survey Respondents from Elementary Schools in Selangor, Malaysia

\begin{tabular}{lcc}
\hline Test Battery & Number & Percentage \\
\hline Total delivered & 480 & 100.00 \\
Total returned & 440 & 91.67 \\
Scorable forms & 4.18 & 87.08 \\
Unscorable forms & 22 & 4.50 \\
\hline
\end{tabular}

Of the 440 returned forms, all were not scorable. A total of 18 subjects failed to answer more than 16 questions from the ATHI Scale. Also, four of the respondents did not answer $50 \%$ of the questions in the demographic data form. Thus the total scorable forms were 418 (87.08\%).

\section{Total Scores of the Respondents} on the ATHI Scale

Total scores on the ATHI by each respondent were computed. Table 2 summarizes the range and mean of the scores of teachers and principals.

As explained in chapter III, a person is considered to have positive attitudes toward handicapped individuals if he/she scores 70 points or more on the ATHI scale. The number and percentage of acceptance or rejection of 
handicapped persons by the teachers and principals is shown in Table 3 .

Table 2

Scores on ATHI scale by Teachers and Principals

\begin{tabular}{ccccc}
\hline Group & Number & Range & Mean & S.D. \\
\hline Teachers & 395 & $\begin{array}{c}75 \\
(22-96)\end{array}$ & 50.64 & 13.64 \\
Principals & 23 & $\begin{array}{c}45 \\
(38-82)\end{array}$ & 61.04 & 12.94
\end{tabular}

Table 3

Percentage of Teachers and Principals Scoring More than 70 points on the ATHI scale

\begin{tabular}{lccc}
\hline Group & Number & $\begin{array}{c}\text { Number of } \\
\text { respondents } \\
\text { scoring 70t }\end{array}$ & $\begin{array}{c}\text { Percent of } \\
\text { respondents } \\
\text { scoring 70+ }\end{array}$ \\
\hline Teachers & 395 & 32 & 8.10 \\
Principals & 23 & 5 & 21.74 \\
Total & 418 & 37 & $4.3 i$ \\
\hline
\end{tabular}

\section{Testing the Hypotheses}

In order to determine whether significant differences existed between the mean scores of groups on the basis of demographic and experiential variables, eight hypotheses 
were tested by means of $\underline{t}$ tests and analysis of variance at the .05 level. In addition, hypotheses regarding differences in responses to individual items on the questionnaire were tested by chi-square. Each hypothesis has been presented in this section and the results of the t tests, ANOVA, and chi-square are presented and discussed.

\section{Hypothesis 1}

There is no significant difference between the mean scores of respondents grouped according to attendance at conferences, workshops, or any other related presentations dealing with special education.

The total subjects responding to this item were 400 . A total of 18 subjects failed to respond to this item. The scores of 400 respondents are presented in Table 4. Thirty

\section{Table 4}

Scores on ATHI by Respondents Attended Presentations Related to Special Education

\begin{tabular}{lccc}
\hline Group & Number & $\begin{array}{c}\text { Number of Ss. } \\
\text { scoring } 70+\end{array}$ & $\begin{array}{c}\text { Percent of Ss. } \\
\text { scoring } 70+\end{array}$ \\
\hline Attended & 42 & 12 & 30.00 \\
Not attended & 358 & 26 & 6.88 \\
Total & 400 & 36 & 9.00 \\
\hline
\end{tabular}

percent of the subjects who attended conferences, workshops, or any other presentations indicated a higher acceptance 
level of handicapped individuals. This percentage is higher than the percentage for respondents who did not attend any presentations relaied to exceptionality. The difference between the two groups was tested by means of the independent $t$ test (see Table 5).

\section{Table 5}

Comparison of Respondents' Scores on ATHI According to Attendance in Presentations Related to Special Education

\begin{tabular}{lcccc}
\hline Group & Number & Mean & S.D. & $\underline{t}$ \\
\hline Attended & 42 & 58.38 & 14.31 & $3.38 *$ \\
Not attended & 358 & 50.57 & 12.89 & \\
\hline
\end{tabular}

${ }^{\star} \mathrm{p}<.05$

The calculated $t$ of 3.38 was significant at .05 level. Thus the null hypothesis was rejected. Educators who attended conferences, workshops, or any other presentations related to special education were found to have significantly higher positive attitudes toward hanäicapped individuals than the educators who were not exposed to such activities. However, any conclusions based on the data presented should be regarded with reservations due to the small number of subjects in the group which attended presentations related to special education. 
Hypothesis 2

There is no significant difference between the mean scores of respondents grouped according to the type of contact with handicapped people (family, friend, student, neighbor, more than one type of contact, and none).

Of the 418 respondents, 195 reported to have contact with one of the various categories given (see Table 6).

Table 6

Scores on ATHI According to the Type of Relationship with Handicapped Individuals

\begin{tabular}{lcccc}
\hline \multicolumn{1}{c}{ Group } & Number & $\begin{array}{c}\text { Mean of } \\
\text { scores }\end{array}$ & $\begin{array}{c}\text { Number of Ss. } \\
\text { scoring } 70+\end{array}$ & $\begin{array}{c}\text { Percent of Ss. } \\
\text { scoring 70+ }\end{array}$ \\
\hline $\begin{array}{l}\text { Members of } \\
\text { the family }\end{array}$ & 29 & 50.51 & 3 & 10.34 \\
Co-worker & 12 & 45.16 & 1 & 8.33 \\
Friend & 28 & 50.04 & 2 & 7.14 \\
Student & 50 & 50.08 & 4 & 8.00 \\
Neighbor & 19 & 48.21 & 2 & 10.53 \\
$\begin{array}{l}\text { More than } \\
\text { one category }\end{array}$ & 57 & 50.17 & 12 & 21.05 \\
No contact & 223 & 47.14 & 17 & 7.62 \\
\hline
\end{tabular}

The difference in the mean scores between the groups were tested by one-way analysis of variance (see Table 7). The $\underline{F}$ calculated value of 3.57 exceeded the critical value of 2.10. Therefore the hypothesis of no difference was rejected. The difference found between the mean scores was further investigated by the post hoc multiple comparison 
(Scheffé) method. It showed that the differences were not significant. The conclusion would be that the significance indicated by ANOVA ( $\underline{F}$ ) would have been caused by unequal sample sizes.

\section{Table 7}

Comparison of Respondents' Scores on ATHI According to Type of contact by Analysis of Variance

\begin{tabular}{lrrrrr}
\hline Source & $\begin{array}{l}\text { Sum of } \\
\text { square }\end{array}$ & df & $\begin{array}{l}\text { Mean } \\
\text { square }\end{array}$ & $\underline{F}$ & FcV \\
\hline $\begin{array}{l}\text { Between } \\
\text { groups }\end{array}$ & 3584.573 & 6 & 597.427 & $3.565 *$ & 2.10 \\
Within & 68885.500 & 411 & 167.605 & & \\
Total & 72470.070 & 417 & & & \\
\hline
\end{tabular}

${ }^{*} \mathrm{p}<.05$.

Hypothesis 3

There is no significant difference between the mean scores of respondents grouped according to the years of teaching experience.

A total of 408 subjects identified their years of teaching experience. The number of subjects who did not indicate their years of experience was ten. The respondents' scores on ATHI are presented in Table 8. Respondents from the group with four to seven years of experience scored slightly higher than the other groups. 
The differences between the mean scores were tested by analysis of variance (see Table 9).

Table 8

Scores on ATHI by Respondents According

to Years of Teaching Experience

\begin{tabular}{lcccc}
\hline \multicolumn{1}{c}{ Group } & Number & $\begin{array}{c}\text { Mean of } \\
\text { scores }\end{array}$ & $\begin{array}{c}\text { Number of Ss. } \\
\text { scoring } 70+\end{array}$ & $\begin{array}{c}\text { Percent of Ss. } \\
\text { scoring 70t }\end{array}$ \\
\hline 3 years & 41 & 49.66 & 5 & 12.20 \\
or less & 65 & 52.42 & 8 & 12.30 \\
$4-7$ years & 29 & 49.69 & 1 & 3.45 \\
$8-10$ years & 74 & 38.83 & 8 & 10.81 \\
$11-15$ & 199 & 33.27 & 18 & 9.05 \\
Years & 10 & 0.00 & 0 & 0.00 \\
16 yearst & 418 & & 40 & 9.56 \\
Not & & & & \\
responded & 199 & & & \\
Total & & & & \\
\hline
\end{tabular}

Table 9

Comparison of Respondents' Scores on ATHI

According to Teaching Experience

by Analysis of Variance

\begin{tabular}{lrrrrr}
\hline Source & $\begin{array}{c}\text { Sum of } \\
\text { squares }\end{array}$ & $\underline{\text { df }}$ & $\begin{array}{c}\text { Mean } \\
\text { squares }\end{array}$ & $\underline{F}$ & $\underline{F}_{C V}$ \\
\hline $\begin{array}{l}\text { Between } \\
\text { groups }\end{array}$ & 154.713 & 3 & 51.571 & 0.302 & 2.60 \\
$\begin{array}{l}\text { Within } \\
\text { groups }\end{array}$ & 35061.473 & 205 & 171.032 & & \\
Total & 35216.188 & 208 & & & \\
\hline
\end{tabular}


The $\underline{F}$ value of .302 was not significant. Therefore the null hypothesis was retained. There is no difference between the mean scores of respondents grouped according to their years of teaching experience.

Hypothesis 4

There is no significant difference between the mean scores of respondents grouped according to the level of education (School certificate and two years teacher training, Higher school certificate and two years teacher training, Bachelor degree and one-year teacher training, and other).

The sample on which testing of this hypothesis took place consisted of 418 subjects. Of the four groups, the respondents with Bachelor degree scored higher $(70+)$ than the other three groups (see Table 10).

A majority of the respondents from the category "Other" indicated having Lower school certificates and three years of teacher training. One of the respondents did not identify the type of academic qualifications possessed. The difference in scores between the groups was tested by analysis of variance (see Table 11).

The $\mathrm{F}$ value of 5.50 was significant at .05 level. Thus the hypothesis 4 was rejected. There is a significant difference between the mean scores of groups according to the level of education. The difference found between the mean scores was further tested by the scheffé method. The 
Table 10

Scores on ATHI by Respondents According

to the Level of Education

\begin{tabular}{lcccc}
\hline \multicolumn{1}{c}{ Group } & Number & $\begin{array}{c}\text { Mean of } \\
\text { scores }\end{array}$ & $\begin{array}{c}\text { Number of } \\
\text { Ss } \begin{array}{c}\text { scored } \\
70+\end{array}\end{array}$ & $\begin{array}{c}\text { Percent of } \\
\text { Ss } \begin{array}{c}\text { scored } \\
70+\end{array}\end{array}$ \\
\hline $\begin{array}{l}\text { School cert. } \\
\text { two years } \\
\text { teach. trng. }\end{array}$ & 328 & 50.06 & 31 & 9.45 \\
$\begin{array}{l}\text { Higher sch. } \\
\text { cert. \& two }\end{array}$ & 26 & 56.35 & & 3.85 \\
$\begin{array}{l}\text { years teach. } \\
\text { trng. }\end{array}$ & & & 1 & 33.33 \\
$\begin{array}{l}\text { Bachelor } \\
\text { degree \& } \\
\text { teach. trng. }\end{array}$ & 3 & 78.67 & 3 & 8.33 \\
$\begin{array}{l}\text { Other } \\
\text { Not } \\
\text { responded }\end{array}$ & 60 & 48.63 & 5 & 9.09 \\
\begin{tabular}{l} 
Total \\
\hline
\end{tabular} & 418 & & 38 & \\
\hline
\end{tabular}

Table 11

Comparison of Respondents' Scores on

ATHI by Analysis of Variance

\begin{tabular}{lrrrrr}
\hline Source & $\begin{array}{c}\text { Sum of } \\
\text { squares }\end{array}$ & $\underline{d f}$ & $\begin{array}{c}\text { Mean } \\
\text { square }\end{array}$ & $\underline{F}$ & $\underline{F}_{C V}$ \\
\hline $\begin{array}{l}\text { Between } \\
\text { groups }\end{array}$ & 2778.809 & 3 & 926.270 & $5.494 *$ & 2.65 \\
$\begin{array}{l}\text { Within } \\
\text { groups }\end{array}$ & 69630.453 & 413 & 168.597 & & \\
Total & 72409.266 & 416 & & & \\
\hline
\end{tabular}

${ }^{*} \mathrm{p}<.05$ 
difference between the school certificate holders and Bachelor degree holders was significant $(\underline{F}=14.43, \underline{p}=$ .05). The difference between Higher school certificate holders and Bachelor degree holders was significant $(\underline{E}=107.26, \underline{p}=.05)$. The difference between Bachelor degree holders and "Other" was significant $(\underline{F}=107.26$, $\mathrm{p}=.05)$. But the differences between School certificate holders and Higher school certificate holders, School certificate holders and "Other," and Higher school certificate holders and "Other" were not significant.

\section{Hypothesis 5}

There is no significant difference between the mean scores of teachers and administrators.

The total subjects responding to this item were 418 . of this, 23 (5.50\%) were administrators (principals) and 395 ( $94.49 \%$ ) were teachers (see Table 12).

Table 12

Scores on ATHI by Teachers and Principals

\begin{tabular}{lccc}
\hline Group & Number & $\begin{array}{c}\text { Number of Ss. } \\
\text { scoring } 70+\end{array}$ & $\begin{array}{c}\text { Percent of Ss. } \\
\text { scoring } 70+\end{array}$ \\
\hline Teachers & 395 & 32 & 8.10 \\
Principals & 23 & 5 & 21.74 \\
\hline
\end{tabular}

The difference between the percentages of principals and teachers scoring more than 70 points was significant. The 
difference in scores was compared by the independent samples t test (see Table 13).

Table 13

Comparison of Teachers' and Principals'

Scores on ATHI by $t$ Test

\begin{tabular}{lccccc}
\hline Group & Number & Mean & S.D. & $s_{\bar{x}}$ & $t$ \\
\hline Teachers & 395 & 61.043 & 13.640 & 2.844 & $3.57 *$ \\
Principals & 23 & 60.640 & 12.945 & 0.651 & \\
\hline
\end{tabular}

$* \underline{p}<.05$

The $t$ of 3.57 exceeded the critical value of 1.96 at .05 level. Therefore the null hypothesis was rejected. However, any conclusions based on the finding should be regarded with reservations, due to the small number of subjects in the group of principals.

Hypothesis 6

There is no significant difference between the mean scores of male and female respondents.

The total male respondents in this category were 109. Of the 109 males, 11 (10.09\%) showed positive acceptance of handicapped people (see Table 14). Of the 309 females in the survey, $28(9.06 \%)$ scored $70+$ on the ATHI scale.

The difference in scores was tested by means of the independent samples $\underline{t}$ test. The test compared the mean score of the males with the females (see Table 15). 
Table 14

Scores on ATHI by Males and Females

\begin{tabular}{lccc}
\hline Group & Number & $\begin{array}{c}\text { Number of Ss. } \\
\text { scoring } 70+\end{array}$ & $\begin{array}{c}\text { Percent of Ss. } \\
\text { scoring } 70+\end{array}$ \\
\hline Male & 109 & 11 & 10.09 \\
Female & 309 & 28 & 9.06 \\
\hline
\end{tabular}

Table 15

Comparison of Male and Female Respondents'

Scores on ATHI by $\underline{t}$ Test

\begin{tabular}{lccccc}
\hline Group & Number & Mean & S.D. & $S_{\bar{x}}$ & $t$ \\
\hline Male & 109 & 53.229 & 13.127 & 1.257 & 1.86 \\
Female & 309 & 50.501 & 13.150 & & \\
\hline
\end{tabular}

The $\underline{t}$ was found to be 1.96. The calculated $\underline{t}$ of 1.86 was not significant. Therefore the hypothesis was retained. There is no significant difference between the acceptance level of male and female respondents.

\section{Hypothesis 7}

There is no significant difference between the mean scores of respondents grouped according to age categories.

A total of 418 respondents were grouped in five age categories as presented in Table 16. 
Table 16

Scores on ATHI by Respondents According to Various Age Groups

\begin{tabular}{lrrrr}
\hline Group & Number & $\begin{array}{c}\text { Mean of } \\
\text { scores }\end{array}$ & $\begin{array}{c}\text { Number of Ss. } \\
\text { scoring 70t }\end{array}$ & $\begin{array}{c}\text { Percent of Ss. } \\
\text { scoring 70t }\end{array}$ \\
\hline $20-27$ years & 72 & 51.42 & 8 & 11.11 \\
$28-34$ years & 67 & 49.48 & 4 & 5.97 \\
$35-41$ years & 117 & 57.86 & 17 & 14.52 \\
$42-51$ years & 146 & 52.47 & 9 & 6.16 \\
$52+$ years & 16 & 48.94 & 3 & 18.75 \\
\hline
\end{tabular}

As shown in Table 16 the last category of the respondents obtained a slightly higher percentage of scores of $70+$. The differences in means were tested by applying one-way analysis of variance. The result of the analysis of variance applied to the group differences is presented in Table 17 .

Table 17

Comparison of the Respondents' Scores on ATHI by Analysis of Variance

\begin{tabular}{lrrrrrr}
\hline Source & $\begin{array}{l}\text { Sum of } \\
\text { square }\end{array}$ & $\underline{\text { df }}$ & $\begin{array}{c}\text { Mean } \\
\text { square }\end{array}$ & $\underline{F}$ & $\underline{F}_{\mathrm{CV}}$ \\
\hline $\begin{array}{l}\text { Between } \\
\text { groups }\end{array}$ & 369.035 & 4 & 92.259 & 0.528 & 2.37 \\
$\begin{array}{l}\text { Within } \\
\text { groups }\end{array}$ & 72101.039 & 413 & 174.579 & & \\
Total & 72470.070 & 417 & & & \\
\hline
\end{tabular}


Since the $F$ in this study was lower than the critical value of 2.37 , the null hypothesis was retained. There is no difference between the mean scores of respondents grouped according to different age groups.

Hypothesis 8

There is no significant difference between the mean scores of different races (Malay, Chinese, Indian, or Other).

Among the respondents there were 235 Malays, 101 Chinese, 75 Indians, and 7 others. Two of the seven respondents from the "Other" group identified themselves as singalese and the other five did not reveal their identity. The percentage of the respondents who scored more than 70 points on the ATHI is presented in Table 18. The difference observed in Table 18 between the mean scores for different races was tested by analysis of variance (see Table 19).

The $\underline{F}$ critical value was found to be 2.60 . The $\underline{E}$ value of 4.991 was significant at .05 level. Therefore the null hypothesis was rejected. There is a significant difference between the mean scores of respondents from different races. The difference found between the mean scores was further tested by the post hoc multiple comparison (Scheffé) method. The difference between Malay and Chinese respondents $\left(\underline{F}=39.87, \underline{F}_{\mathrm{CV}}=7.80\right.$, $\mathrm{p}<.05)$ and the difference between Malay and Indian 
Table 18

Scores on ATHI by Respondents According

to Various Race Groups

\begin{tabular}{lcccc}
\hline Group & Number & $\begin{array}{c}\text { Mean of } \\
\text { scores }\end{array}$ & $\begin{array}{c}\text { Number of Ss. } \\
\text { scoring } 70+\end{array}$ & $\begin{array}{c}\text { Percent of Ss. } \\
\text { scoring } 70+\end{array}$ \\
\hline Malay & 235 & 42.47 & 15 & 6.38 \\
Chinese & 101 & 52.25 & 11 & 10.89 \\
Indians & 75 & 55.45 & 11 & 14.66 \\
Other & 7 & 56.29 & 3 & 42.86 \\
\hline
\end{tabular}

Table 19

Comparison of the Respondents' Scores

on ATHI by Analysis of Variance

\begin{tabular}{lrrrrr}
\hline Source & $\begin{array}{l}\text { Sum of } \\
\text { square }\end{array}$ & df & $\begin{array}{c}\text { Mean } \\
\text { square }\end{array}$ & $\underline{E}$ & $\underline{F}_{C V}$ \\
\hline $\begin{array}{l}\text { Between } \\
\text { groups }\end{array}$ & 2529.581 & 3 & 843.194 & $4.991 *$ & 2.60 \\
$\begin{array}{l}\text { Within } \\
\text { groups }\end{array}$ & 69940.492 & 414 & 168.938 & & \\
Total & 72470.070 & 417 & & & \\
\hline
\end{tabular}

$* \mathrm{p}<.05$ 


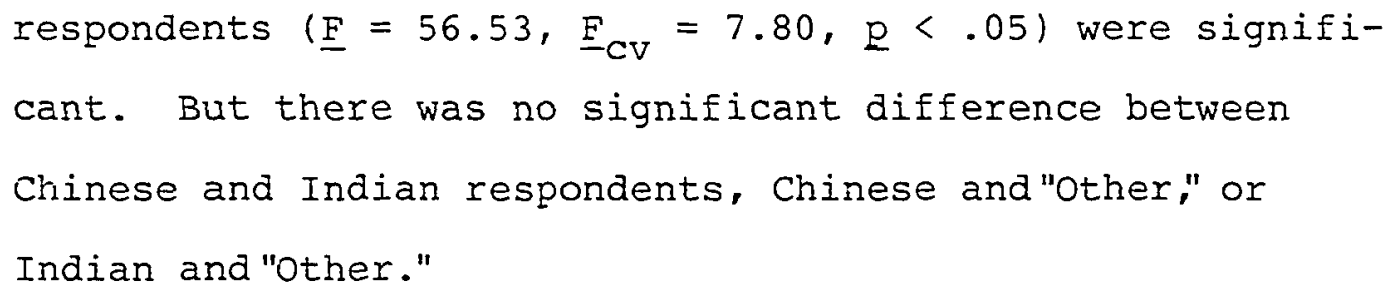

\section{Respondents' Choice of Delivery of Instruction for the Handicapped}

A total of 418 subjects responded to this item (Appendix B, Part II, \#I) on which the respondents had to indicate their opinion on the best way of delivering instruction to handicapped individuals (see Table 20).

Table 20
Number and Percentage of Respondents' Choice of Delivery of Instruction to the Handicapped

\begin{tabular}{lcc}
\multicolumn{1}{c}{ Group } & Number & Percentage \\
\hline $\begin{array}{l}\text { Segregated } \\
\text { special school }\end{array}$ & 252 & 60.29 \\
$\begin{array}{l}\text { Segregated special } \\
\text { classes in } \\
\text { regular school }\end{array}$ & 77 & \\
$\begin{array}{l}\text { Segregated } \\
\text { residential } \\
\text { school } \\
\text { Other }\end{array}$ & 89 & 18.42 \\
\hline
\end{tabular}

As presented in Table 20 segregated special schools were found to be the most popular choice for teaching handicapped students. 
Respondents' Priority of Working with Different

Categories of Exceptionality

As stated in Chapter III the respondents were asked to indicate their order of preference for working with different categories of handicappism--blind, deaf, learning disabled, emotionally disturbed, and mentally retarded. The data presented in this section are based on the responses to that item (Appendix B, Part II, \#2).

The total subjects providing the responses to this item were 351 out of 418. A total of 67 (16.02\%) failed to respond to this item. The reason for the failure to respond to this item is not known. It is possible that either the respondents did not exactly understand the question or they did not have any preference at all. The number and percentage of each area of exceptionality preferred is presented in Table 21 .

The difference in the percentage of preference observed was tested by chi-square. The difference between the expected percentage and observed percentage was significant, $\underline{\chi}^{2}=37.97, \underline{\mathrm{df}}=4, \underline{\chi}_{\mathrm{CV}}^{2}=9.488, \underline{\mathrm{p}}<.05$. Thus, the most preferred group was the learning disabled, and this was followed by blind, deaf, emotionally disturbed, and mentally recarded. The difference in preference for blind and deaf seemed to be very close. 
Table 21

Number and Percentage of Respondents' Preference for Working with Various Categories

of Exceptionality

\begin{tabular}{lrr}
\hline \multicolumn{1}{c}{$\begin{array}{c}\text { Area of } \\
\text { exceptionality }\end{array}$} & Number & Percentage \\
\hline Blind & 70 & 16.74 \\
Deaf & 67 & 16.02 \\
Learning disabled & 111 & 26.56 \\
Emotionally disturbed & 64 & 15.31 \\
Mentally retarded & 39 & 9.33 \\
Not responded & 67 & 16.02 \\
Total & 418 & 100.00 \\
\hline
\end{tabular}

Analysis of Respondents' Scores on Individual Items of ATHI Scale

The 20 items on the ATHI scale were concerned with the respondents' opinion on a family's discipline of their handicapped children on education practices for the handicapped, on self-concept of the handicapped, on socialization of the handicapped, and on the working capabilities of the handicapped. By dividing the survey respondents into categories depending upon their sex, age, academic qualifications, attendance in presentations related to special education, experience, race, and contact with handicapped persons, it was possible to determine whether each item in the scale was independent of the respondents' characteristics upon which they were grouped. The 
chi-square statistical analysis procedure was used to measure the significance of difference between groups. The .05 level of significance was used as the probability level for determining whether or not the observed differences were significant. Table 22 shows the hypotheses of independence which were rejected for each item based on demographic and experiential variables. Chi-square analysis showed that the item number one was not independent of sex, age, academic qualifications, or contact. A significantly larger percentage of male respondents indicated that handicapped children should be disciplined less strictly than other children.

Table 22

Hypotheses of Independence Rejected

\begin{tabular}{ll}
\hline \multicolumn{1}{c}{ Variables } & \multicolumn{1}{c}{ Item Number* } \\
\hline Sex & $1,5,18,19$ \\
Age & $3,5,15$ \\
Race & $1,2,3,4,5,7,8,9,10,11$, \\
& $12,13,16,17,18,19,20$ \\
Appointment & $1,8,7,9$ \\
Academic qualification & $1,8,17,19$ \\
Attendance & 1,16 \\
Experience & $3,8,10$ \\
Contact & $1,2,7,10$ \\
& \\
\hline
\end{tabular}

*(Appendix A contains test items.) 
All respondents (three) with Bachelor degrees disagreed that parents of handicapped children should be less strict than parents of nonhandicapped children. Persons with more education were more likely to disagree with this item. A total of 63 of of the Malay respondents felt that handicapped children should not be treated differently than nonhandicapped children. Persons with contact with handicapped people were much more likely to support disciplining handicapped children to the same extent as nonhandicapped children.

For item number five which elicited responses on respondents' perceptions about handicapped people's selfconcept, $35 \%$ of the male respondents and $45 \%$ of the female respondents regarded handicapped people the same as anyone else. The percentages of respondents from various age groups who agreed on this item ranged from $29.16 \%$ to $56.25 \%$. Item number seven on job related factors was found to be not independent of race, appointment, and contact with handicapped people. The Indian respondents were less favorable of this statement. Sixty-six percent of the Indian respondents disagreed that it was suitable for handicapped people to live in a segregated community and work. A larger percentage of the Chinese and Malay respondents supported segregation of handicapped people. Item number eight on respondents' perception of the government's responsibility for the welfare of the handicapped was not found to be independent of race and 
professional experience of the respondents. Of the Malay respondents, $78.29 \%$ agreed that the government should take care of handicapped people as compared to $62 \%$ Indian respondents. From the different categories of experience groups, the group with 10-15 scored the highest percentage $(83 \%)$ in support of government care for handicapped as compared to the lowest percentage (59.798) of respondents with 16 years or more experience.

Item number ten on handicapped persons' academic capabilities was found to be dependent upon the respondents' experience and contact with handicapped individuals. Sixtysix percent of the respondents with the highest experience level perceived the handicapped as having limitations in academic capabilities, whereas $53.65 \%$ respondents with the least experience level regarded them to have less potential for academic achievement. This indicated that more experience in working with handicapped students promotes less expectations of handicapped persons' academic capabilities. The hypothesis on this item was not rejected on age group level. The researcher expected that older subjects might be more negative, but the results did not support this expectation.

Item number 17 examining respondents' opinion on the socialization capability of handicapped people, found that $100 \%$ of the respondents with Bachelor degrees disagreed and said handicapped persons could have a normal social life. The range of disagreement ranged from $31 \%$ for the 
High School certificate holders to $100 \%$ of the Bachelor degree holders. However, caution should be taken in interpreting this item as only three subjects had Bachelor degrees.

A total of $35.71 \%$ of the respondents who attended conferences did not regard handicapped people as more easily upset than nonhandicapped people. This is compared to $27 \%$ of the respondents who did not have any exposure to special education presentations.

Item number 18 on handicapped persons' self-concept showed more male than female respondents felt that handicapped persons felt good about themselves.

Although significant differences related to sex and education occurred on item number 19, approximately 85\% of all respondents believed that people have to be careful of what they say when they are with handicapped people.

As seen in Table 22 (page 68), most of the items were found to be dependent on the demographic variable, race. The Indian respondents were found to be more favorable in their perceptions of handicapped people than Malay and Chinese respondents. The higher acceptance level of Indian respondents toward handicapped persons may be attributed to either the cultural difference or the higher level of education in the field of exceptionality.

Some items did not show significant differences in how groups of subjects responded. However, the majority of subjects responded with negative beliefs about the 
handicapped on some items. The subjects seemed to believe that handicapped people feel sorry for themselves. The majority of the subjects believed that handicapped persons cannot lead a normal life and they should have segregated schools and communities in which to live. Another unanimous perception of the handicapped by the respondents was that handicapped people have low self-concept, are grouchy, and easily hurt by comments made by others.

\section{Discussion of Results}

The investigation of the effect of the level of acceptance-rejection of exceptional individuals revealed that only $4.31 \%$ of the educators possessed favorable attitudes toward disabled people. This indicated that the majority of the educators possess negative attitudes toward disabled individuals. If educators' unfavorable attitudes can cause a negative impact on the mental and emotional. development of their students, every effort should be made to find methods to modify their attitudes in a positive direction toward handicapped individuals. Educators with exposure to special education presentations were found to possess more favorable attitudes than educators who did not have such experiences. Sensitizing educators through workshops, seminars, or conferences seems to have considerable influence in modifying attitudes in a positive direction. 
The hypothesis regarding the effect of contact and number of years of teaching experience on attitude did not indicate a gain in positive attitudes. This result suggested that contact or increase in teaching experiences does not necessarily develop empathy or acceptance of disabled persons.

The respondents with the highest level of education (Bachelor degree) were significantly different from respondents with lower levels of education (school certificate and two years of teacher training). Although the number of degree holding subjects in this study was very limited, the level of education was found to be highly significant in their acceptance level of disabled individuals. If higher education can modify attitudes positively, the Ministry of Education should be aware of its impact on teachers and should consider making it a requirement for teachers to have higher educational levels than the levels currently required for selection of elementary schoolteachers.

Investigations of difference between attitudes of teachers and administrators showed that a very small percentage of these respondents possessed positive attitudes toward exceptional persons. The test for difference between administrators and teachers revealed that administrators were more positive toward handicapped persons than teachers. Although the number of principals in this study was 1 imited to 30 , this finding needs 
attention. The difference may be due to the fact that administrators usually do not have much experience with handicapped learners in their school. Also as a leader, the principal might feel that he/she should be more adapting to individual differences. The difference between these two groups should be further investigated.

Investigations of the attitudes of males and females toward the disabled indicated no significant difference between the groups. Sex of the respondents did not seem to have any impact on the ievel of attitudes. Some studies of the impact of sex on attitudes in the United States showed that women have consistently scored higher than males. The finding of no difference between the groups among Malaysian subjects seems to be rather interesting. It would be valuable to investigate further by a comparative study of men and women from Malaysia and the United States.

Investigations of the relationship of age and attitude did not indicate a significant difference. Although there was not a significant difference between the age of the educators and their attitudes toward disabled persons as measured by the ATHI, it should be noted that the age groupings were arbitrarily conceived. Different results might have been obtained if the age category in this study had been better controlled.

The hypothesis regarding the differences in attitudes of various races indicated that Indian ethnic groups were 
more favorable toward disabled persons. The higher acceptance level of Indian respondents toward handicapped persons may be attributed to two possible reasons. Cultural differences associated with the ethnic groups may have had an impact on the result, or the significance associated with higher level of education in the field of exceptionality may have been a contributing factor.

The respondents indicated a hierarchy of preference for various categories of exceptionalities. Learning disabled persons were found to be the most preferred group. This was followed by physically handicapped (blind and deaf), emotionally disturbed, and mentally retarded people. A possible explanation for the preference of physically handicapped to the emotionally disturbed and the mentally retarded may be attributed to the fact that educational training for deaf and blind people received attention much earlier and educators had an opportunity to realize the capabilities of the blind and deaf. This might indicate that as educators become more aware of the potential of handicapped people, they may become more accepting.

The respondents' choice of delivery of instruction for the handicapped indicated that a majority of the respondents preferred segregated schools as the best setting for delivering instruction to disabled learners. But educators with higher degree of acceptance level chose segregated classes in regular schools as the best 
environment for delivering instruction. It would appear that as a person's acceptance level of exceptional individuals increases, his/her willingness to accommodate or regard handicapped persons similar to the normal population also will increase.

Realizing the negative impact of segregated schools on handicapped persons, advanced nations such as the United States and Scandinavian countries are making every effort to integrate handicapped persons into the mainstream. Malaysian educational leaders should consider the findings of this study with the relationship of positive attitudes and acceptance and find methods to sensitize and modify educators' attitudes in a positive direction. This can serve to encourage Malaysian educators to consider the concept of mainstreaming.

Hypotheses regarding differences on the individual items of the ATHI indicated that overall the respondents regarded handicapped persons as having low self-esteem, being easily hurt by comments made by others, being difficult to get along with, and being grouchy. It is reasonable to believe that as long as respondents possess these types of negative perceptions about handicapped individuals, acceptance of exceptional individuals will be very low. Therefore, leaders in educational development should take responsibility to ameliorate the negative beliefs about handicapped persons by providing appropriate 
education and training for personnel who deliver educational services. Such training programs should emphasize an increased irteraction with handicapped persons. 


\section{CHAPTER V}

SUMMARY, CONCLUSIONS, IMPLICATIONS,

AND RECOMMENDATIONS

\section{Summary}

The Malaysian peoples' increasing awareness of the needs of their handicapped population and lack of Malaysian special education research suggested the need for an attitudinal study of educators in Malaysia. The overall purpose of the study was to gather basic data for recommendations for teacher training programs and program development projects that would improve educational services for handicapped children in Malaysia. A major focus of the data collection was to investigate the attitudes of teachers and administrators toward nandicapped persons in Malaysia and to examine if there were differences among educators based on demographic and experiential variables. A secondary focus of this study was to determine if there was a difference between the attitudes of administrators (principals) and teachers attitudes. The study also examined the question of whether there was a priority of preference among educators for working with different categories of handicapped individua's. Finally, 
an attempt was made to investigate the Malaysian educators' choice of instruction for their handicapped individuals.

Research Design and Instrument

The research method selected for this study was a survey. A review of previous attitudinal studies in the United States revealed the Attitude Toward Handicapped Individuals scale (ATHI) as a valid and reliable instrument for assessing attitudes toward handicapped persons. This scale was translated into Bahasa Malaysia, the national language of Malaysia. Translation validation of this instrument was established by a pilot study among 30 Malaysians. The pilot study subjects were chosen from a cross-section of Malaysian nationals to determine if there would be any difficulties in responding to the translation or format of the questionnaire.

A questionnaire checklist consisting of eight items was utilized to gather demographic and experiential variables of the respondents. In addition to this personal data form, two open-ended questions were included to examine educators' choice of delivery of instruction and order of preference for working with various categories of handicapped people.

\section{Sample}

The sample of this study included 450 elementary schoolteachers and 30 principals randomly selected from a total of 30 Malay medium elementary schools in Malaysia. These 
30 schools were selected from a total of 116 Malay medium elementary schools in selangor.

\section{Procedure}

The test battery was mailed to the researcher's colleague in Malaysia and the colleague distributed the survey instrument to the selected subjects. The completed questionnaires were collected by the colleague and were mailed back to the researcher. Atotal of $92 \%$ of the questionnaires were returned. Of the total survey returned, $87 \%$ of the questionnaires were scorable.

\section{Analysis of Data}

Analysis of data was accomplished by applying $t$ tests, one-way analysis of variance, and chi-square. All analyses were computer assisted.

\section{Findings}

According to the ATHI scale individuals scoring 70 points or more are regarded as having positive attitudes toward handicapped persons. Results received from elementary schoolteachers and principals in this study revealed that only $4.31 \%$ of the educators possessed favorable attitudes toward the handicapped population. This indicated that a majority of the educators view handicapped persons as aifferent from the rest of the population. 
Investigations of the relationship between attitudes and experiential and demographic variables brought forth interesting findings. The results are summarized below for each of the hypotheses tested:

Hypothesis one stated that there will not be a significant difference between the mean scores of respondents grouped according to attendance at conferences, workshops, or any other related presentations dealing with special education. The analysis of the scores indicated a significant difference between the respondents who attended and did not attend presentations related to special education $(\underline{t}=3.38, \underline{p}<.05)$. Utilizing sensitivity training like workshops, seminars, or conferences seemed to modify attitudes in a positive direction.

Hypothesis two stated that there will not be a significant difference between the mean scores of respondents grouped according to the type of contact with handicapped people. The analysis of variance indicated a significant difference between the groups, $\underline{E}(6,417)=3.565, \underline{\mathrm{p}}<.05$. Further analysis of this result by the scheffé method did not show that the differences were significant. Having contact with handicapped persons does not necessarily produce positive attitudes toward them.

Hypothesis three stated that there will not be a significant difference between the mean scores of respondents grouped according to the years of teaching 
experience. The analysis of variance did not indicate any significant difference between the groups.

Hypothesis four stated that there will not be a significant difference between the mean scores of respondents grouped according to the level of education. The analysis of variance indicated a significant difference between the groups, $\mathrm{F}(3,416)=5.494, \mathrm{p}<.05$. Further analysis of the result by scheffé method revealed a significant difference between school certificate holders and Bachelor degree holders $(\underline{F}=14.43, \mathrm{p}<.05)$. But the differences between School certificate holders and Higher school certificate holders, and School certificate holders and "Other" were not significant.

Hypothesis five stated that there will not be a significant difference between teachers and administrators. The analysis of scores indicated a significant difference between administrators and teachers ( $\underline{t}=3.57, \mathrm{p}<.05$ ). Administrators were more positive than teachers. Hypothesis six stated that there will not be a significant difference between the mean scores of male and female respondents. The analysis of scores by $t$ test did not indicate a significant difference between male and female respondents.

Hypothesis seven stated that there will not be a significant difference between the mean scores of respondents grouped according to various age categories. The 
analysis of variance did not indicate a significant difference between the respondents of various age groups. Hypothesis eight stated that there will not be a significant difference between the mean scores of different races (Malays, Chinese, Indians, and Other). The analysis of variance indicated a significant difference between the groups, $\underline{F}=4.991, \underline{p}<.05$. Further analysis by the Scheffé method indicated a significant difference between Malay and Chinese respondents $(\underline{F}=39.87, \underline{p}<.05)$, and Malay and Indian respondents $(\underline{F}=56.53, \underline{p}<.05)$. But no significant differences between Chinese vs. Indian respondents, Chinese vs. "Other," or Indian vs. "Other" were found. Thus, respondents from the Indian ethnic group were found to be more accepting of handicapped persons than respondents from other ethnic groups. The higher acceptance level of Indian respondents toward handicapped persons may be attributed to two possible reasons. Cultural differences associated with the ethnic groups may have had an impact on the result, or the significance associated with higher level of education may have been a contributing factor.

The respondents' preference for various categories of exceptionalities indicated that the first preference by the teachers and principals was for the learning disabled and the least preference was for the mentally retarded persons. The order of preference for various categories of exceptional persons in ranking order was learning 
disabled, physically handicapped (blind, deaf), emotionally disturbed, and mentally retarded persons.

The respondents' choice for delivery of instruction for the handicapped indicated a majority of the respondents preferred segregated schools as the best way to deliver. instruction to disabled learners. Educators with higher degree of acceptance level chose segregated classes in regular schools as the best setting for teaching disabled individuals.

Certain individual items from the ATHI scale were found to be dependent on the demographic and experiential variables studied. Respondents with higher levels of education and training in special education were found to regard disabled people as very similar to the rest of the population. The majority of the respondents believed disabled people had a low self-esteem, were difficult to get along with, and were grouchy. The respondents also believed that disabled people should be housed in segregated schools and communities.

\section{Conclusions}

Based on the results of the study, the following conclusions were made:

The elementary schoolteachers and principals possessed very unfavorable stereotypic attitudes toward disabled people. The principals were found to be more accepting of the disabled than the teachers. But the result cannot 
be generalized as the number of principals in this study were limited to only 30 .

The educators' attitudes were significantly affected by their level of education, exposure to presentations related to special education, and their race. More advanced educational experience seemed to elevate attitudes of people in a positive direction, and as a result they were more empathetic toward disabled persons. Special education background also was found to play an active role in modifying attitudes in a positive direction.

The educators' first preference among various categories of handicapped persons was found to be for learning disabled persons and the least preference for mentally retarded persons. The preference in ranking order was the learning disabled, the blind, the deaf, the emotionally disturbed, and the mentally retarded. The educators possessed stereotypic perceptions of the disabled population. They regarded the disabled as a definitely separate group in respect to their life style, socialization capability, mental and intellectual potential and selfconcept.

\section{Implications}

Major implications of this study suggest the need to develop a teacher training program model, including both inservice and preservice training, and a program development model for handicapped persons in Malaysia. A corollary 
implication involves the need to set forth content recommendations. Following are guidelines for both the teacher training model and the program development model.

\section{Inservice Training}

The results of the study revealed that only $12 \%$ of the educators had attended some sort of presentation related to special education. The results also indicated that educators with such special education experiences were more positive toward handicapped persons. It is not a requirement in Malaysia for all regular education teachers to attend inservice training for the education of handicapped persons. This may be due to the lack of development in the field of special education. The Ministry of Education in Malaysia should consider it as essential to educate and sensitize regular education teachers about disabled learners. As explained in Chapter I, the mildy mentally handicapped, learning disabled, and mildly emotionally disturbed children are in the mainstream of the school because of the lack of special education facilities. These children are often misunderstood and neglected. If regular education teachers are sensitized to the needs of the handicapped learners, they will be better prepared to serve the exceptional population who are already in the mainstream.

The urgency and the immensity or the need for staff trained in educating handicapped learners draws attention 
to the requirement for formulation of an inservice training program which can be rapidly and realistically implemented. An inservice training program or on-the-job training program has significant advantages. One advantage is the fact that such training makes possible an immediate response to the existing needs. Also, an on-the-job training program represents a valuable means of ensuring that the selected staffs possess the necessary personal qualifications (Boucebci \& Brau, 1981).

The findings from the item analysis of the ATHI Scale provided insight into areas which required attention. The following is a summary of the needs of Malaysian educators, based on this study, for increasing favorable attitudes toward handicapped persons:

1. Providing knowledge of various handicapping conditions which affect educational development within students.

2. Determining student potential and limitations in learning.

3. Eliciting the issue and importance of integration of handicapped into the mainstream of the society.

4. Understanding problems which may be encountered by the family of the hardicapped.

5. Determining job related skills of handicapped individuals.

The results of tine study also indicated that both principals and teachers in Malaysia possessea negative 
attitudes toward handicapped individuals. Therefore, it should be planned to direct inservice training program efforts to both principals and teachers. The data also showed that Malay and Chinese respondents possessed comparatively higher negative attitudes than the respondents from the Indian ethnic group. This finding should be taken into consideration by emphasizing the need for all Malay and Chinese respondents to attend inservice training. Thus the purpose of the inservice program should be to:

1. Provide an opportunity for participants to gain knowledge about various categories of handicapping conditions.

2. Identify the status of existing programs and areas which need attention.

3. Demonstrate the needs of understanding handicapped students as a whole, including a focus on:

--mental and emotional potential of the handicapped --interpersonal skills --self-concept of the handicapped.

4. Recognize the importance of integration and normalization of handicapped persons.

5. Sensitize the participants with needs and support for the family of the handicapped. 


\section{Objectives}

The objectives of an inservice program should be to increase understanding and involvement of teachers in programs related to special education and to increase positive attitudes toward disabled learners. Thus, an inservice training program should provide supportive learning experiences for all teachers who are currently employed in the classroom. Information, assistance, and knowledge which teachers gain from the inservice workshops, seminars, or conferences have been shown to make significant modifications in the attitudes of teachers and principals (Pecheone \& Gable, 1978).

In order to achieve the purposes and objectives of an effective inservice program, the researcher recommends that the content of the training program should be based on information from broad disciplines associated with exceptionalities and sensitization of disabilities. Two major activities suggested for delivering content of the inservice program involves use of a "lecture strategy," and use of "handicapped awareness simulation."

\section{Lecture Strategy}

Lectures should be delivered which cover topics dealing with psychology, identification and assessment of the handicapped, counseling, curriculum for the handicapped, and behavior management techniques. Each lecture should be followed by a group discussion on the covered topic and 
should be further enhanced by showing related films on exceptionality.

Handicapped Awareness Simulation

Theoretical information can serve to raise consciousness levels regarding disability. In addition to being consciousness raisers of disability, certain exercises are essential to sensitize participants to the range of existing disabilities as well as to different realities experienced by individuals with varying disabilities (Gerlach, 1979). Gerlach explained the importance of role-playing in sensitization exercises. Volunteers should be chosen from the participants for role-playing exercises. The instructor should make it clear to the volunteers that the participants will have an opportunity to experience to some extent what it is like to be disabled. Role-playing or simulations focusing on various categories of exceptionality such as motor disability (problem of moving around), sensory disability (problem of seeing and hearing), and learning disability (perceptual and academic problems) should be included. After such simulation activities each role-players' experiences as handicapped should be explored and discussed.

\section{Preservice Training}

The result of the study indicated that educators without any training or courses in special education had 
very negative attitudes toward handicapped individuals. The result of the study also revealed that those educators holding a Bachelor degree exhibited the highest level of acceptance of handicapped persons. Thus, the implications of this research rest in the application of the findings to the development of programs for preservice teachers. Findings of this study should be taken into consideration by making it a requirement for teachers to have a Bachelor degree to teach at the elementary school level. Current minimum requirements for teaching at the elementary school level in Malaysia is noted below:

1. Secondary school (high school) certificate and Two-Year Teacher Training Certificate.

2. Higher school (2-year college) certificate and Two-Year Teacher Training Certificate.

\section{Suggested Preservice Teacher}

\section{Training Program}

Degree program. As described in chapter IV, the findings of this study indicated that educators with the highest level of education (Bachelor degree) exhibited higher acceptance of handicapped persons. Considering this finding, if a preservice teacher training program offering a Bachelor degree is initiated, it can be further investigated and determined if higher education can develop favorable attitudes toward handicapped individuals. This researcher therefore suggests changing the current 
requirements for teacher qualifications to a four-year program culminating in a Bachelor degree in Education which can serve as an experimental study to further examine the validity of such a program. The suggested Bachelor degree program should have the following options:

1. Students entering the undergraduate program may choose to have two majors in either Elementary School teaching or Secondary School teaching.

2. One major in Elementary Education and one major in Special Education Generic (General Special Education).

3. One major in Secondary School level and one major in Special Education Generic.

Students choosing the second or third option should be offered a certificate enabling him/her to teach regular education and/or special education.

Teacher training certificate program. Depending upon the local needs and the availability of teacher trainers, other appropriate training models may be necessary. Training for teachers, paraprofessionals (teacher aids), and parents should be developed at regional levels. Such programs couid be offered at the existing teacher training colleges which offer two-year training. But the major emphasis of this program should be to educate teachers to educate handicapped learners. 
Philosophy

A program offering training in Education should focus on the basic philosophy of fostering an attitude among trainees that every child has the right to an educational experience which will enable him/her to develop his/her maximum potential in all areas of living. In order to facilitate the students releasing of potential, the teachers must believe $i_{i n}$ every learners' right to learn the most they can learn (Anderson, Greer, \& Odle, 1978).

\section{Competency}

In order to meet the aforementioned goal of education, it is necessary to provide the teacher trainee with sufficient competent courses and increased opportunities for interaction with handicapped learners. Thus the objectives of such a program should be as follows:

1. To provide the student with skills and experiences necessary for diagnosing the educational needs of normal and exceptional children.

2. To provide the student with competencies necessary to design and carry out educational and instructional programs for normal and exceptional children.

3. To provide the student with competencies necessary to collect data, interpret data, and critique behavioral research studies.

4. To provide the student with practical experiences in a variety of supervised educational programs for normal and exceptional children. 
In order to accomplish the objectives listed above, the teacher trainee should show a minimum level of competency in the following areas:

1. Knowledge of the development of normal children and handicapped children.

2. Counseling students.

3. Communicating with parents and professionals.

4. Describing and assessing student behavior.

5. Developing and planning instructional process.

A program emphasizing theory and practical experiences would provide competent teachers (Joyce \& Weil, 1980). This would also maximize educational quality and access as well as increased accountability in the field of teacher education (McAshan, 1979; Hall \& Howard, 1977).

\section{Program Development}

An analysis of the item regarding the setting for program delivery for handicapped persons showed that a majority of respondents felt initial planning for delivery of services should focus on segregated schools. Further analysis of this item showed that educators with the highest acceptance of handicapped persons preferred integrated school settings. Thus, the result of this study also showed that the preference of educators for integration of handicapped learners with nonhandicapped learners depends on their positive attitudes. As a result, every attempt should be made to modify educators' attitudes 
in a positive direction to assist them in developing acceptance of handicapped learners. As favorable attitudes increase, integrated schools for disabled learners should be introduced and promoted on a national basis.

\section{Special Schools}

The item dealing with the opinion on the responsibility of government in taking care of handicapped people indicated that a majority of respondents believed it was the government's responsibility to provide adequate shelter and educational training for the handicapped. Thus, based on the result of this study the researcher recommends that the Ministry of Education, Malaysia should give immediate attention to the organization of special schools for handicapped learners. As described in Chapter II, only 28 of the handicapped population in Malaysia have the opportunity to attend school due to the shortage of educational facilities for handicapped learners. Given the condition that the Ministry of Education will establish special schools on a national level, most of the handicapped learners would have the opportunity to attend schools and develop their potential abilities and skills.

\section{Resource Rooms}

As explained earlier in the inservice training section of this chapter, the mildly handicapped learners in Malaysia are already in the mainstream of schools. Provision should be made to give special attention to these pupils by 
introducing resource rooms with resource teachers. Resource teachers can assist the regular class teachers who are instructing the exceptional students by providing them with support services (Mandell \& Fiscus, 1981). As inservice training increases, there will be more teachers who are better qualified to attend to the individual needs and problems of disabled learners through professional and efficient strategies. It is possible to serve 15-20 students in a resource room where children will have the opportunity for receiving individualized or personalized instruction. Thus, by the means of resource rooms, the learners would receive specialized assistance in their learning problem areas (Mandell \& Fiscus, 1981).

\section{Early Intervention}

Early intervention programs for high-risk children in the United States have been shown to accelerate the sound mental and physical development of handicapped children (Kirk \& Gallagher, 1979). Bearing this in mind, the Ministry of Education should consider providing early educational programs for high-risk children aged two and above. Programs for identifying these high-risk children through proper assessment procedures should also be initiated.

A noncategorical approach should be used for children in the early intervention programs. It has often been difficult to determine one specific category of 
exceptionality into which the child fits (Ierner, Czudnowski, \& Goldenberg, 1981). Since the current assessment tools are not definitive enough to allow for labeling of young children as mertally retarded, emotionally disturbed, or learning disabled, programs should be designed to meet functional needs rather than to create discrete and separate categories for young children (Lerner et al., 1981). Also, labeling has proven to produce negative impact on the emotional and mental development of chilaren (Hallahan \& Kauffman, 1977).

\section{Adult Programs}

Programs should also be initiated to serve handicapped adults to develop job skills, independent living skills, and custodial care when necessary. These should be in the form of sheltered workshops and group homes.

Sheltered workshops. In sheltered workshops handicapped persons would have the opportunity to work under the supervision of trained personnel. In such environments, handicapped individuals can work in settings without the typical demands of the world of work. The skills they learn from this type of environment can lead them to competitive employment and can help them develop a healthy self-concept through participation in productive work activities (Mandell \& Fiscus, 1981). Sheltered workshops should include work on jobs under contract to private 
industries. There should also be provision for furnishing handicapped trainees with monetary rewards based on their competency.

Group homes. Group homes consisting of 5 to 20 people should be introduced for handicapped adults. Group homes have proven to be a good type of residential facility for handicapped adults working in sheltered workshops (Heward \& Orlansky, 1980). These homes should provide a family like atmosphere for its residents and should be under the supervision of qualified house parents.

Group homes can vary in purposes. Some can be principally residential in nature and represent a permanent piacement for their clients. In this type of setting, educational training in self-care, daily living skills, interpersonal relations, and recreational skills should be provided. A group home can also serve as a halfway house where the primary aim should be to prepare the handicapped adult for a more independent living situation (Sellin, 1979).

The location of group homes should be in a residential area where residents would have facilities for shopping, schools, public transportation, and recreational facilities. In planning a group home, careful consideration should be given to the size and location factors in oraer to provide normal living conditions for handicapped individuals (Wolfensberger, 1972). 


\section{Recommendations for Further Research}

The recommendations listed below are for further research in the field of attitudes and special education.

1. The subjects in this study were from only one state in Malaysia. Perhaps further research involving subjects selected on a national basis would enhance the generalization of this study.

2. An investigation should be conducted on the effect of higher educational level and attitudes. Greater acceptance of the disabled people by respondents with Bachelor degrees was obtained in this study. The number of degree holders in this study were comparatively very small. Further research with läger sample of Bachelor degrees should be conducted.

3. Only elementary schoolteachers and principals were included in this study. Further research should be conducted to assess attitudes of secondary school (junior high and high school) teachers and principals.

4. Further research should be conducted by using ethnographic research in which the researcher would have the opportunity to observe the natural behavior and interactions of educators with disabled students. Results could be then compared with results of the survey research method.

5. The number of principals in this study was very limited. Further research should be conducted using a 
larger sample of principals in order to compare the attitudes of teachers and principals.

6. Further research should be carried out to investigate those factors which caused respondents from the Indian ethnic group to possess greater acceptance of exceptional individuals.

7. The influence of demographic variables such as socio-economic level, religion, or geographic area of the respondents were not included in this study. A study including these variables should be conducted.

8. A comparative study of Malaysian educators with educators from advanced countries such as the United States should be conducted. If educators from advanced countries possess higher level of acceptance levels, further research should be conducted to pinpoint the underlying factors associated with their higher positive attitudes, including training they might have received.

9. A comparative study of Malaysian educators and educators from other Asian countries, such as Singapore or Thailand might be worthwhile, for a more indepth analysis of other developing Asian countries.

10. Other continued attitudinal studies with parents, business personnel, school age children, and religious leaders should be conducted. The attitudes of these segments of the population are believed to have a substantial impact on disabled persons. 
11. The survey instrument used in this study was a translated version of the instrument developed in the United States. There is a need for attitudinal instruments which are locally developed and validated in Malaysia.

12. Further research should be conducted to investigate the effects of different modalities on attitudinal change toward handicapped persons. Studying the effect of video, audio, and live presentations of handicapped persons on the attitudes of educators represents a possible example.

13. A simple random sampling technique was used in this survey research. A survey with a stratified sampling might help to clarify the results of this study for the effect of unequal or unbalanced group sizes. 


\section{BIBLIOGRAPHY}

Allport, G. W. (1950). The nature of personality, Selected papers. Reading, Massachusetts: AddisonWesley.

Anderson, C. I. (1964). School health practice. Saint Louis: Mosby Co.

Anderson, R. M., Greer, J. G., \& Odle, S. J. (1978). Individualizing educational materials for special children in the mainstream. Baltimore: University Park Press.

Aukayanagul, B. (1979). Comparing effectiveness of the use of selected instructional techniques in modifying negative or stereotypic attitudes of non-disabled individuals in Thailand. Unpublished doctoral dissertation, University of Northern Colorado, Greeley, Colorado.

Barngrover, E. E. (1971). A study of educators' preferences in special education programs. Exceptional Children, $37,754-755$.

Bell, A. H. (1962). Attitudes of selected rehabilitation workers and other hospital employees toward the physically disabled. Psychological Reports, 10, $183-186$. 
Biackweil, R. B. (1972). Study of effective ana ineffective teachers of the trainable mentally retarded. Exception Children, 39, 139-142.

Bogardus, E. S. (1925). Measuring social distances. Journal of Applied Sociology, 9 , 216-226. Boucebci, M., \& Brau, M. T. (1981). Training specialized staff for the mentally handicapped: An approach for developing countries. Assignment Children, UNICEF, 53/54, 105-113.

Brooks, L. B., \& Bransford, L. A. (1971). Modification of teachers' attitude towards exceptional children. Exceptional Children, 31, 259-260. Burgner, I. A. (1977). The special education services for mentally retarded in Asia. Mental Retardation, $15,12-13$.

Chua, T. T. (1983, April). In Statistics show that education facilities for the disabled inadequate, A need for special schools, See, C. I. Kuala Lumpur (Malaysia), Malay Mail, pp. 8-9. Comb, R. H., \& Harper, J. I. (1967). Effects of labels on attitudes of educators toward handicapped children. Exceptional Children, 33, 399-403.

Conine, T. A. (1968). Teachers' attitudes toward disabled persons. Unpublished doctoral dissertation, Indiana University, Bloomington, Indiana. 
Dailey, J. L., \& Halpin, G. (1981). Modifying undergraduates' attitudes toward the handicapped by videotapes. The Journal of Special Education, 15, $337-339$.

Davis, E. W. (1981). Principals' attitudes toward placement of mildly and moderately handicapped pupils. The Journal for Special Educators, 17, 265-269.

Donaldson, J. (1974). Effects of live, video, and audio presentations by a panel of physically disabled individuals on attitude toward disabled persons. Unpublished doctoral dissertation, University of Kentucky, Lexington, Kentucky.

Donaldson, J. (1980). Changing attitudes toward handicapped persons, A review and analysis of research. Exceptional Children, 46, 504-513.

Dunn, L. M. (1968). Special education for the mildly retarded: Is much of it justifiable? Exceptional Children, 35, 5-22.

Evans, J. H. (1976). Changing attitudes toward disabled persons: An experimental study. Rehabilitation Counseling Bulletin, 19, 572-579.

Fine, M. J. (1967). Attitudes of regular and special class teachers toward the educable mentally retarded child. Exceptional Children, 33, 429-430. Flynn, M. T. (1978). Ratings of educable mentally handicapped students by regular and special education teachers. Exceptional Children, 44, 539-540. 
Foley, J. D. (1978). Teacher attitudes toward the handicapped and placement preferences for exceptional students. Dissertation Abstracts International, 39, 2-A. (University Microfilms No. 773)

Fonosch, G. G., \& Schwab, O. I. (1981). Attitudes of selected university faculty members toward disabled students. Journal of College Student Personnel, 22 , $229-235$.

Foster, V., \& Keech, V. (1977). Teacher reactions to the label of educable mentally retarded. Education and Training of the Mentally Retarded, 12, 307-311. Gerlach, K. P. (1979). Activities for involvement: Inservice ideas for attitudinal change and awareness. Chicago, Illinois: Augustana College. (ERIC Document Reproduction Service No. ED 177 795)

Gibson, C. J. (1980). School administrator attitudes towards handicapped individuals. Unpublished master's thesis, California State University, Long Beach. Gottlieb, J. (1972). Bi-cultural study of attitude change and behavior toward retardates. Unpublished doctoral dissertation, Yeshiva University, New York. Gottlieb, J., \& Corman, L. (1975). Public attitudes toward mentally retarded children. American Journal of Mental Deficiency, $\underline{41}, 469-473$. Gozali, J. (1971). The relationship between age and attitude toward disabled persons. Gerontology, 2, $280-291$. 
Gullick, J. M. (1969). Malaysia. New York: Frederic

A. Praeger.

Gullotta, R. H., \& Harper,J. I. (1967). Effects of labels

on attitudes of educators toward handicapped children.

Exceptional Children, 33, 399-403.

Gullotta, T. (1974). Teacher attitudes toward the moderately disturbed child. Exceptional Children, 4l, $49-50$.

Hall, G. E., \& Howard, J. L. (1977). Competency-based education, A process for the improvement of education. New Jersey: Prentice-Hall.

Hallahan, D. P., \& Kauffman, J. M. (1977). Labels, categories, behaviors: ED, LD, and EMR reconsidered. The Journal of Special Education, 11, 139-147.

Haring, N. J. (1978). Behavior of Exceptional Children. Columbus: Charles E. Merrill.

Haring, N. J., Stern, G. G., \& Cruickshank, W. M. (1978). Attitudes of educators toward exceptional children. Connecticut: Greenwood Press. Harasymiw, S. J., \& Horne, M. D. (1976). Integration of handicapped children: Its effect on teachers. Education, 96, $153-158$.

Heward, W. I., \& Orlansky, M. D. (1980). Exceptional

Chilaren. Columbus: Charles E. Merrill. Hinkle, D. E., Wiersma, W., \& Jurs, S. A. (1979). Applied statistics for the behavioral sciences. Chicago: Rand McNaliy. 
Hollinger, C. S., \& Jones, R. L. (1970). Community attitudes toward slow learners and mental retardates: What is in a name? Mental Retardation, 8 , 19-23. Horne, M. D. (1978). How attitudes are measured: A review of investigations of peer, and parent attitude toward the handicapped. Princeton, New Jersey: ERIC Clearinghouse on Tests, Measurement and Evaluation. (ERIC Document Reproduction Service No. ED 198 154)

Hudson, F., Graham, S., \& Warner, M. (1979). Mainstreaming: An examination of the attitudes and needs of regular classroom teachers. Learning Disability Quarterly, $\underline{2}, 58-62$. Jacobson, E., Kumata, H., \& Gullahorn, J.E. (1960). Cross-cultural contributions to attitudinai research. Public Opinion Quarterly, 24, 205-223.

Johnson, G. O. (1962). Special education for the mentally handicapped--A paradox. Exceptional Children, 29, 6269.

Jones, E. I. (1963). The courtesy bias in south-east Asian surveys. International Social Science Journal, 15, $70-76$. Jordan, J. E. (1968). Attitudes toward education and physicaliy disabled persons in eleven nations. Published doctoral dissertation. East Lansing: Michigan State University Press. Joyce, B., \& Weil, M. (1980). Models of teaching (2nd ed.). New Jersey: Prentice-Hall. 
Kasiwat, S. (1975). Significance of attitudes of three different population groups toward physically handicapped children in Thailand. Unpublished master's thesis, University of Kansas, Lawrence, Kansas.

Kaufman, D. J. (1977). Effects of contact instruction on regular classroom teachers' attitudes toward the mentally retarded. Dissertation Aostracts International, 38, 2-A. (University Microfilms No. 729)

Kennon, A. F., \& Sandoval, J. (1978). Teacher attitudes toward the educable mentally retarded. Education and Training of the Mentally Retarded, 13, 139-145.

Kerlinger, F. N. (1964). Foundations of behavioral research. New York: Holt, Rinehart and Winston. Kingsley, R. F. (1967). Prevailing attituaes toward exceptional children. Education, 87, 426-430. Kirk, S., \& Gallägher, J. (1979). Educating exceptional children. Boston: Houghton Mifflin.

Kurzberg, P. A. (1978). A survey of selected Iowa principals' and superintendents' attitudes toward and knowledge of programming for handicapped stlidents in the least restrictive environment. Unpublished doctoral dissertation, The University of Iowa, Iowa City, Iowa. Larivee, B. (1981). Effects of inservice training intensity on teachers' attitudes toward mainstreaming. Exceptional Children, 48, 34-39. 
Lazar, A. I. (1973). Attitude toward handicapped individual scale. Unpublished attitude scale, California State University, Long Beach, California. Lazar, A. L., \& Denham, C. (1974, April). Comparison of ATDP and ATHI scores with six groups of university majors. Paper presented at the 52nd annual conference; Council of Exceptional Children, New York. Lazar, A. I., \& Stodden, R. (1977). A study of the ATHI and ATDP scales. DOPHHH Journal, $\underline{3}, 6-9$. Lazar, A. I., Stodden, R., \& Sullivan, N. V. (1976). A comparison of attitudes held by male and female school administrators toward instructional goals, personal adjustment and the handicapped. Rehabilitation Literature, 37, 198-201.

Lerner, J., Czudnowski, C. M., \& Goldenberg, D. (1981). Special education for the early childhood years. New Jersey: Prentice-Hall. Leyser, Y., Abrams, P., \& Lipscomb, E. (1982). Modifying attitudes of prospective elementary school teachers toward mainstreaming. The Journal for Special Educators, 18, 1-9.

Likert, R. A. (1932). A technique for the measurement of attitudes. Archeological Psychology, 140, 1-55. Mandell, J. C., \& Fiscus, E. (1981). Understanding exceptional people. Minnesota: West Publishing Co. McAshan, H. H. (1979). Competency-based education and behavioral objectives. New Jersey: Englewood Cliffs. 
McDaniel, L. (1982). Changing vocational teachers' attitudes toward the handicapped. Exceptional Children, 48, $377-378$.

Menlo, A. A. (1978). Comparison of school related perceptions, attitudes, and values of teachers in three countries. Ann Arbor, Michigan: Michigan University. (ERIC Document Reproduction Service No. ED 164 483) Mia, A., Islam, H. Mã., \& Ali, S. Ma. (1981). Situation of handicapped children in Bangladesh. Assignment Children, UNICEF, 53/54, 199-214.

Mitchell, R. E. (1965). Survey materials collected in the developing countries. International Social Science Journal, 17, 665-685. Moffitt, J. C. (1932). An analysis of race prejudice. Educational Administration and Supervising, 18, 641-648. Moore, J., \& Fine, M. J. (1978). Regular and special class teachers' perceptions of normal and exceptional children and their attitudes toward mainstreaming. Psychology in the Schools, 15, 253-259. Morton, L. A. (1978). Effecting attitudinal change toward physically disabled students in higher education. Dissertation Abstracts International, 38, 8-A. (University Microfilms No. 4610-4611) Murphy, A. T. (1960). Attitudes of educators toward the visually handicapped. The Sight Saving Review, 30 , $157-161$. 
Naor, M., \& Milgram, R. M. (1980). Two preservice strategies for preparing regular class teachers for mainstreaming. Exceptional Children, 47, 127-129. Newman, J. (1976). Faculty attitude toward handicapped. Journal of Rehabilitation Literature, 37, 194-197. Nong, Y. B. (1977). The relevancy of performance-based teacher education to Malaysian teacher preparation programs. Unpublished doctoral dissertation, United States International University, San Diego, California. Nooman, R. (1967) Personality determinants in attitude toward disability. Unpublished doctoral dissertation, University of Florida, Gainesville, Florida. Ozyurck, M. (1977). Effects of live, audio, and print presentations of a discussion about physical disabilities on attitude modification toward disabled persons in Turkey. Unpublished doctoral dissertation, University of Northern Colorado, Greely, Colorado. Panda, K. C., \& Bartel, N. R. (1972). Teacher perception of exceptional children. Journal of Special Education, $\underline{6}, 261-266$. Parish, T. S., Eads, G. M., Reece, N. H., \& Piscitallo, M. A. (1977). Assessment and attempted modification of teachers' attitudes toward handicapped children. Perceptual and Motor Skills, 44, 540-542. Payne, R., \& Murray, C. (1974). Principals' attitudes toward integration of the handicapped. Exceptional Children, $41,123-125$. 
Pecheone, R. I., \& Gable, R. K. (1978). The identification of inservice needs and their relationship to teacher demographic characteristics, attitude toward and knowledge of mildly handicapped children. Storrs: Connecticut University. (ERIC Document Peproduction Service No. ED 156 628)

Proctor, D. I. (1967). An investigation of the relationship between knowledge of exceptional children, kind and amount of experience, and attitudes toward their classroom integration. Dissertation Abstracts International, 28, 1721-A. (University Microfilms No. $67-14,538)$

Rapier, J., Adelson, R., \& Croke, K. (1972). Changes in children's attitude toward the physically handicapped. Exceptional Children, 39, 219-223. Rhoads, R. G. (1978). A study of a teacher education technique for increasing individualized instruction methods in the classroom. Unpublishsd doctoral dissertation, Saint Louis University, Saint Louis, Missouri.

Rosenthal, R., \& Jacobson, L. F. (1968). Teacher expectations for the disabled. Scientific American, $218,19-23$. Sato, T. (1980). A cross-cultural study of attitudes toward handicapped individuals in Japan and the United States. Unpublished master's thesis, California state University, Long Beach, California. 
Schmelkin, P. L. (1981). Teachers' and non-teachers' attitude toward integration of handicapped children. Exceptional Children, $\underline{48}, 42-48$.

See, C. I. (1983, April). Statistics show that education facilities for the disabled inadequate, A need for special schools. Kuala Lumpur (Malaysia), Malay Mail, pp. 8-9.

Sellin, D. F. (1979). Mental retardation: Nature and Advocacy. Boston: Allyn and Bacon.

Sen, K. A. (1975). Mental Retardation in India: A short description. Mental Retardation, 14, 11-13.

Shavelson, R. J. (1977). Introduction to statistical reasoning and procedures for the design and analysis of research in the behavioral sciences. Los Angles, California: University of California.

Shotel, J. R. Iano, R., \& McGettigan, J. F. (1972). Teacher attitudes associated with the integration of handicapped children. Exceptional Children, 38, 677-683. Sippel, H., Lazar, A. L., \& D'Alonzo, B. (1976). Changing attitude toward TMR through an integrated recreation program. Long Beach,California: California State University. (ERIC Document Reproduction Service No. ED 123 860)

Sipperstein, G. N., \& Gottlieb, J. (1978). Parents' and teachers' attitudes toward mildiy and severely retarded children. Mental Retardation, 16, 321-322. 
Smith, T. E. C. (1979). Attitudes of principals and seachers toward mainstreaming handicapped children. Journal for Special Educators, 16, 89-95.

Sinith, T. E. C., Flexer, R. W., \& Singleman, C. K. (1980). Attitudes of secondary school principals toward the learning disabled. Journal of Learning Disabilities, $\underline{13}, 62-64$.

Stodden, R., Graves, M. \& Lazar, A. L. (1973). The relationship between the ATDP and ATHI scales for assessing attitudes. Long Beach, California: California State University. (ERIC Document Reproduction Service No. ED 085 947)

Thurstone, L. L., \& Chave, E. J. (1929). The measurement of attitude. Chicago: University of Chicago Press. Warren, S. A., Turner, D. R., \& Brody, D. S. (1967). Can education students' attitudes toward the retarded be changed? Mental Retardation, 8 , 230-233. Williams, R. J. (1977). An investigation of regular class teachers' attitudes towards the mainstreaming of four categories of mildly handicapped students. Dissertation Abstracts International, 38, 5-A. (University Microfilms No. 2708-2709)

Wolfensberger, W. (1972). Citizen advocacy for the handicapped: An cverview (DPHEW Pub. No. (OS) 72-24). Washington, DC: President's Committee on Mental Retardation. 
Wong, W., \& Tompar-Ties, P. A. (1981). A community program in the Philippines. Assignment Children, UNICEF, 53/54, 197-199.

Woody, J. A. (1974). Attitudes of principals toward the handicapped. Unpublished master's thesis, California State University, Long Beach, California.

Yuker, H. E. (1965). Attitudes as a determinant of behavior. Journal of Rehabilitation, 31, 15-17. Yuker, H. E., Block, J., \& Younng, J. (1966). The measurement of attitudes toward disabled persons. New York: Human Resources Center. 
APPENDICES

116

Reproduced with permission of the copyright owner. Further reproduction prohibited without permission. 
APPENDIX A

ATHI SCALE

117

Reproduced with permission of the copyright owner. Further reproduction prohibited without permission. 


\section{ATHI SCALE \\ by}

\section{Al Lazar}

(Together with the translated version in Bahasa Malaysia)

Tandakan di sabelah kiri tiap-tiap ayat mengikut kadar persetujuan anda. Semua ayat mesti ditandakan. Tuliskan $1,2,3,4,5$, dan 6 berdasarkan persetujuan anda terhadap ayat-ayat tersebut. Kefahaman soalan-soalan adalah terpulang kepada tuan/puan tetapi sila jawab semua soalan. (Mark each statement in the left margin according to how much you agree or disagree with it. Please mark every one. Write 1, 2, 3, 4,5 and 6 depending on how you feel in each case. You may interpret the questions in any way you please but respond to every one).

6: Saya sangat bersetuju ( I agree very much)

5: Saya cukup bersetuju (I agree pretty much)

4: Saya kurang bersetuju (I agree very little)
3: Saya sadikit tidak bersetuju (I disagree a little)

2: Saya cukup tidak bersetuju (I disagree pretty much)

1: Saya sangat tidak bersetuju (I disagree very much)

1. Ibubapa kanak-kanak cacat sapatutnya kurang berkeras daripada lain-lain ibubapa. (Parents of handicapped children should be less strict than other parents).

2. Orang-orang cacat adalah sama bijaknya dengan orang-orang yang tidak cacat. (Handicapped persons are just as intelligent as non-handicapped ones).

3. Orang-orang cacat selalunya mudah didampingi berbanding dengan orang-orang lain. (Handicapped people are usually easier to get along with than other people).

4. Kebanyakan orang-orang cacat menyesali ke atas diri mereka. (Most handicapped people feel sorry for themselves). 
5. Orang-orang cacat adalah saperti orang-orang lain. (Handicapped people are the same as anyone else).

6. Tidak sapatutnya di adakan sekolah-sekolah khas untok orang-orang cacat. (There should not be special schools for handicapped children).

7. Adalah lebih baik bagi orang-orang cacat hidup dan bekerja di kalangan masyarakat tertentu. (It would be best for handicapped persons to live and work in special communities).

8. Adahlah tanggongjawab Kerajaan untok menjaga orangorang cacat. (It is up to the government to take care of handicapped persons).

9. Kebanyakan orang-orang cacat terlalu banyak risau. (Most handicapped people worry a great deal).

10. Orang-orang cacat tidak sepatutnya diharapkan taraf yang sama dengan orang-orang yang tidak cacat. (Handicapped people should not be expected to meet the same standards as non-handicapped).

11. Orang-orang cacat sama bergembira sapertimana orang-orang yang tidak cacat. (Handicapped people are as happy as non-handicapped people).

12. Orang-orang yang teruk kecacatannya tidak kurang susahnya untok ải dampingi berbanding dengan orang-orang yang kurang kecacatannya. (Severely handicapped people are no harder to get along with than those with minor handicaps.

13. Adalah mustahil bagi orang-orang cacat untok menjalani penghidupan yang sempurna. (It is almost impossible for a handicapped person to lead a normal life).

14. Anda tidak saharusnya terlalu berharap orang-orang cacat. (You should not expect too much from handicapped people). 
15. Orang-orang cacat lebih suka menyimpan kebanyakan masa kepada diri mereka sendiri. (Handicapped people tend to keep to themselves most of the time).

16. Orang-orang cacat lebih mudah tersinggong daripada orang-orang tidak cacat. (Handicapped people are more easily upset than non-handicapped people).

17. Orang-orang cacat tidak boleh menjalani penghidupan sosial yang biasa. (Handicapped persons cannot have a normal social life).

18. Kebanyakan orang-orang cacat merasakan mereka tidak bagitu pintar saperti orang-orang lain. (Most handicapped people feel that they are not as good as other people).

19. Anda hendaklah berwaspada di atas apa yang anda berkata apabila bersama orang-orang cacat. (You have to be careful of what you say when you are with handicapped people).

20. Orang-orang cacat selalunya perenggut. (Handicapped people are often grouchy). 
APPENDIX B

PERSENDIRIAN BORANG DATA

(Personal Data Form) 
PERSENDIRIAN BORANG DATA

(Personal Data Form)

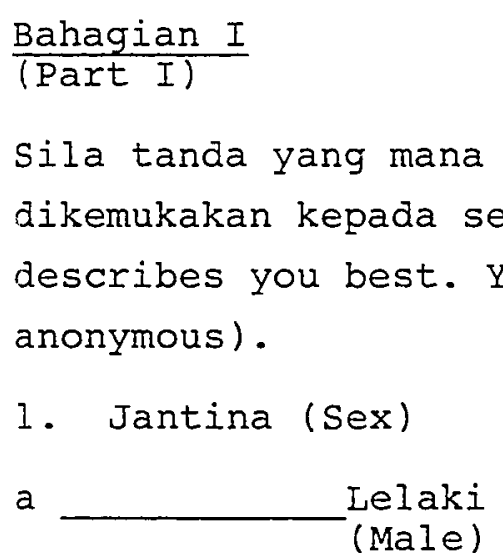

b Perempuan (Male) (Female)

2. Umor (Age)

a $20-27$

b $28-34$

C $35-41$

a $42-51$

d $52+$

3. Bangsa (Race)

a Melayu

b Cina

c India
d Lain-lain (Nyaiakan dengan jelas) (Other- Specify)

4. Jawatan sekerang (Present Appointment)

a Guru besar (Principal) $\mathrm{b}$ Guru (Teacher) 
5. Kelayakan akademic (academic qualification)

a

Sijil Pelajaran Malaysia dan 2 tahun Berkursus di Maktab Pergurauan (School Certificate and 2 years Teacher Training)

$\mathrm{b}$ Sijil Tinggi Pelajaran dan 2 tahun Berkursus di Maktab Perguruan (Higher School Certificate and 2 years Teacher Training)

C Ijazah Sarjana Muda dan Latihan Perguruan (Bachelors degree and Teacher Training)

d Lain-lain (Nyatakan dengan jelas) (Other-specify)

6. Adakah tuan/puan pernah menghadiri kursus-kursus, seminar, atau pun apa apa persembahan/penyampaian mengenai hal-hal kecacatan. (Have you attended any speciai courses, seminars, or any other presentations related to handicappism)

a Yes

b No

If Yes Specify:

a Kursus
(course)

Jumlah masa menghadiri (hours attended

b

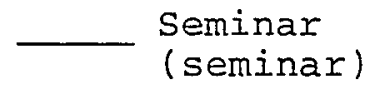

Jumlah masa menghadiri

(hours attended)
Sila sebutkan tajok kursus (Please list title)
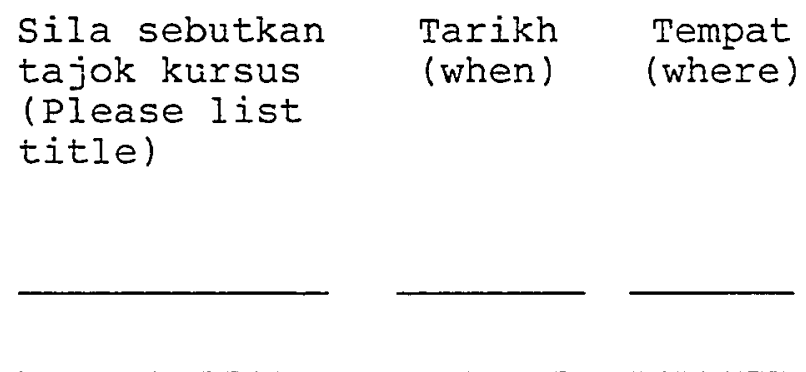

Sila sebutkan tajok seminar (Please list seminar title)
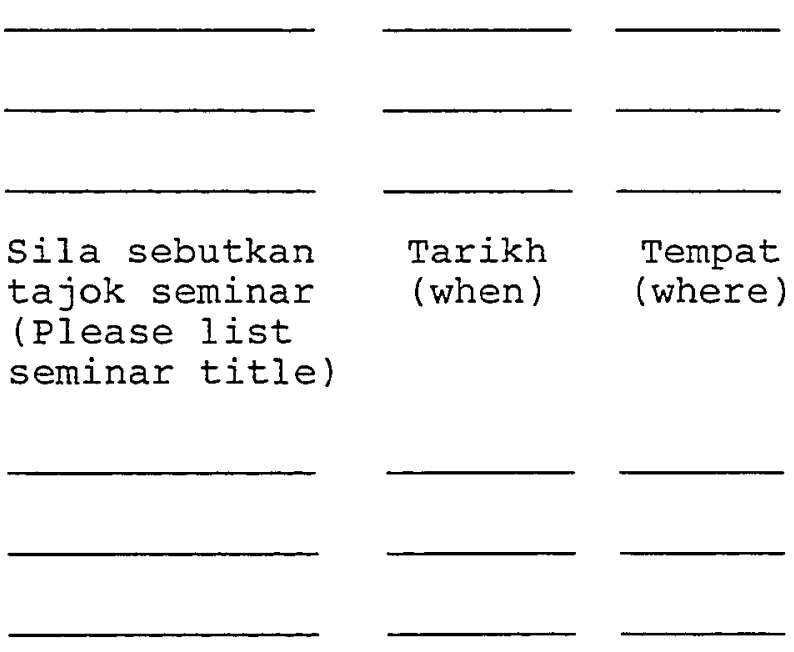
c

$-\begin{gathered}\text { Bengkel } \\ \text { (workshop) }\end{gathered}$

Jumlah masa

menghadiri

(hours

attended)

d

L Lain-lain

(sila nyatakan

apa jenis)

(other-specify)

\footnotetext{
Jumlah masa

menghadiri

(hours attended)

$\underline{-}$
}

Sila sebutkan tajok bengkel

Tarikh

(when)

Tempat (Please list workshop title)
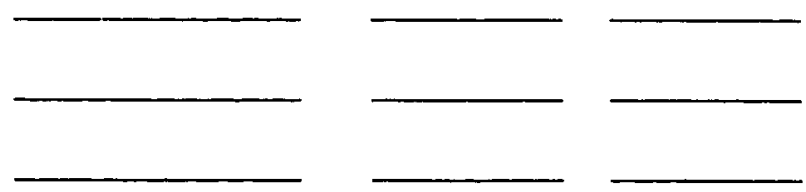

Sila sebutkan

Tarikh (when)

Tempat tajok (Please list title)

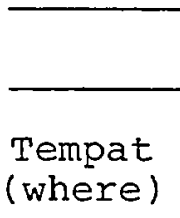

7. Sila tandakan dibawah jumlah tahun tuan/puan telah bekerja sebagai guru besar/guru. (Please indicate below the number of years you have been working as a principal/teacher).
a 3 tahun atau kurang ( 3 years or less)
c 8-10 years
e Melebihi 16 tahun (More than 16 years)
b 4-7 years
a 11-15 years

8. Sekiranya tuan/puan pernah mengenali anggota-anggota cacat dalam katagori yang disebut di bawah, sila tandakan $(\checkmark)$. Sekiranya tuan/puan pernah mengenali anggota-anggota cacat lebih dari satu katagori, sila nyatakan darjah pengenalan tuan/puan di antara katagori tersebut dengan menggunakan angka $1,2,3,4,5$ dan 6 . Angka 1 menunjukkan kenal sepenuhnya, angka 2 kurang mengenal dan seterusnya sehingga angka 6). If you have had contact with a handicapped person in any of the categories, please tick $(\checkmark)$. If :ou have had contact with a handicapped person in more than one category, please indicate them in ranking order according to the degree of contact, by numbering $1,2,3,4,5$ and 6 starting with 1 for the greatest contact, 2 for slightly less contact, and so on). 

a
Keluarga atau saudara
b
$-\begin{aligned} & \text { Teman sekerja } \\ & \text { (co-worker) }\end{aligned}$ (Members of your family)
c
Kawan
d
Penuntut tuan/puan
(friena)
(your student)
e
Jiran
(neighbor)
$f-\frac{\text { Tidak ada }}{\text { (none) }}$

Bahagian II

(Part II)

1. Pada pendapat anda, apa ka cara yank paling sesuai untuk mengajar kanak-kanak cacat? (Tanda satu). In your opinion what is the best way of teaching the handicapped? (Tick one).

a Sekolah khas untuk kanak-kanak cacat. (Separate special schools for the handicapped)

$\mathrm{b}$ Darjah khas untuk kanak-kanak cacat dalam sekolah biasa. (Separate classes for the handicapped in regular schools)

C Sekolah khas berasrama (Special residential schools)

d Lain-lain-Nyatakan (Others-Specify)

2. Sila tanda yang mana sesuai diperengan 1. Please tick where applicable in paragraph il.

Perenggan 2 memberi definisasi

(paragraph 2 gives definitions)

1. Sekiranya anggota cacat ditempatkan di darjah/ sekolah tuan/puan, sila nyatakan keutamaan pemilihan tuan/puan diatas gulongan kanak-kanak manakah yang tuan/puan lebih suka menerimanya-Nyatakan pemilihan ini dengail mengunnakan angka $1,2,3,4,5$ mengikut kadar keutaman tuan/puan. (If handicapped children are placed in your class/scinool please indicate your order of preference for types of handicapped children you like to work with--indicate the order by numbering $1,2,3,4,5$ in order of priority). 
a

C

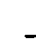

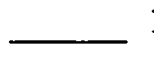

Buta (blind)

Tidak keupayaan belajar d (Learning disabled)

Kebuntuan Pemikiran

(mentally retarded) $\mathrm{b}$

d Emosi yang
terganggu
(emotionally
disturbed)

2. Definisasi (definitions)

Buta - Anggota yang tiada penglihatan atau tiada mempunyai penglihatan yang lemah di dalam mengenali sasuatu.

(Blind) - (Individuals who have no vision or no significant usable vision).

Pekak - Anggota yang telah hilang pendengaran atau kurang pendengaran sehingga tidak dapat memahami apa yang diperkatakan.

(Deaf) - (Individuals who have hearing loss of such a degree that hearing is too little for understanding speech).

Tiada keupayaan belajar--Sasaorang menunjukkan kekurangan pencapaian didalam sasuatu bidang tertentu atau bidang-bidang saperti kira-kira, penulisan, pengejaan atau pembacaan.

(Learning Disabled)--(Individuals who exhibit lack of achievement in a specific area or areas such as math, writing, spelling, or reading).

Emosi yang Terganggu--Sasaorang yang berkelakuan luarbiasa semasa di dalam keadaan yang biasa.

(Emotionally Disturbed)--(Individuals who behave abnormally under normal circumstances).

Kebuntuan pemikiran--Sasaorang yang lemah daya pemikirannya dimana penerimaan/penyesuaian dan kemahiran sosial sangat berkurangan.

(Mentally Retarded)--(Individuals whose intelligence is significantly below average, and in whom adaptive and social skills are deficient). 
APPENDIX C

COVER LETTER FOR SURVEY 
I am a Malaysian who is currently working on a doctoral degree in Educational Leadership at the University of San Diego, California, U.S.A. The attached survey instrument is for the purpose of conducting research for my doctoral dissertation. The result of this study will help in planning programs in education for the handicapped.

Your cooperation is requested in completing the survey. Receiving completed surveys from every educator who was asked to participate is necessary so that enough information is obtained to aid in program planning.

Your responses will be treated in strict professional confidence and will be used only in combination with others from all over the state. At no time will you or your school be identified in any published reports.

I will appreciate your completing the attached survey and returning it to me within ten days, in the self-addressed stamped envelope enclosed. The result of this study will be sent to you following the completion of the dissertation. Thank you very much for your assistance.

Sincerely yours,

Rachel Mathews

Doctoral candidate 


\section{APPENDIX D}

PERMISSION LETTER FROM THE MINISTRY

OF EDUCATION, MALAYSIA 
BAHAGIAN PERANCANGAN DAN PENYELIDIKAN PELAJARAN, KEMENTERIAN PELAJARAN, TINGKAT 21-23,

BANGUNAN BANK PERTANIAN, LEBOH PASAR BESAR, KUALA LUMPUR

Surat Tuan:

21 hb. April. 1983.

Puan Rachel Mathews,

18, Lengkok Zaaba,

Taman iun Dr. Ismail,

Kuala Lumpur.

Puen,

Kebenaran bagi menjalankan Kajian ke Sekolah-sekolah

Adalah dimaklumkan bahawa permohonan pihak puan untuk menjalankan kajian mengenai "Teachers' and Administrators' Attitudes Toward the Education of the Handicapped in Malaysia," telah diluluskan. Kelulusan ini adalah berdasarkan hanya kepada apa yang terkandung di dalam Cadangan Penyelidikar yang puan kemukakan ke Bahagian ini. Puan juga dikenendaki menghantar senaskah kajian pihak puan ke Bahagian ini sebaik saja seiesa: kelak.

Sekian.

" BERKHIDMAT UNTUK NEGARA "

Saya yang menurut perintah,

( MUTAMD HASAN BIN ABDUL RAHMAN)

Bahagian Perancangan den Penyeliaiken Pelajaran,

b.p. Ketua Setizusaha,

Kementerian Pelapjaran Malaysia.

$-/ k s$ 
APPENDIX E

SCORING THE ATHI

131

Reproduced with permission of the copyright owner. Further reproduction prohibited without permission. 


\section{SCORING THE ATHI}

1. Change the signs of the positively worded items: $2,5,6,11$, and 12 .

2. Add all of the responses algebraically.

3. Change the sign of the algebraic resultant.

4. Add the constant of +60 . 